\title{
On the use of the correction factor with Japanese ozonesonde data
}

\author{
G. A. Morris ${ }^{1}$, G. Labow ${ }^{2}$, H. Akimoto ${ }^{3}$, M. Takigawa ${ }^{4}$, M. Fujiwara ${ }^{5}$, F. Hasebe ${ }^{5}$, J. Hirokawa ${ }^{5}$, and T. Koide ${ }^{6}$ \\ ${ }^{1}$ Dept. of Physics and Astronomy, Valparaiso University, Valparaiso, IN, USA \\ ${ }^{2}$ Science Systems and Applications, Inc., Lanham, MD and NASA Goddard Space Flight Center, Greenbelt, MD, USA \\ ${ }^{3}$ Asia Center for Air Pollution Research, Niigata, Japan \\ ${ }^{4}$ Japan Agency for Marine-Earth Science and Technology, Yokohama, Japan \\ ${ }^{5}$ Faculty of Environmental Earth Sciences, Hokkaido University, Sapporo, Japan \\ ${ }^{6}$ Atmospheric Environment Division, Japan Meteorological Agency, Tokyo, Japan
}

Correspondence to: G. A. Morris (gary.morris@valpo.edu)

Received: 26 April 2012 - Published in Atmos. Chem. Phys. Discuss.: 22 June 2012

Revised: 11 December 2012 - Accepted: 27 December 2012 - Published: 1 February 2013

\begin{abstract}
In submitting data to the World Meteorological Organization (WMO) World Ozone and Ultraviolet Data Center (WOUDC), numerous ozonesonde stations include a correction factor (CF) that multiplies ozone concentration profile data so that the columns computed agree with column measurements from co-located groundbased and/or overpassing satellite instruments. We evaluate this practice through an examination of data from four Japanese ozonesonde stations: Kagoshima, Naha, Sapporo, and Tsukuba. While agreement between the sonde columns and Total Ozone Mapping Spectrometer (TOMS) or Ozone Mapping Instrument (OMI) is improved by use of the CF, agreement between the sonde ozone concentrations reported near the surface and data from surface monitors near the launch sites is negatively impacted. In addition, we find the agreement between the mean sonde columns without the $\mathrm{CF}$ and the ground-based Dobson instrument columns is improved by $\sim 1.5 \%$ by using the McPeters et al. (1997) balloon burst climatology rather than the constant mixing ratio assumption (that has been used for the data in the WOUDC archive) for the above burst height column estimate. Limited comparisons of coincident ozonesonde profiles from Hokkaido University with those in the WOUDC database suggest that while the application of the CFs in the stratosphere improves agreement, it negatively impacts the agreement in the troposphere. Finally and importantly, unexplained trends and changing trends in the CFs appear over the last 20 years. The overall trend in the reported CFs for the four Japanese ozonesonde stations from 1990-2010 is $(-0.264 \pm 0.036) \times 10^{-2} \mathrm{yr}^{-1}$; but from 1993-1999 the
\end{abstract}

trend is $(-2.18 \pm 0.14) \times 10^{-2} \mathrm{yr}^{-1}$ and from 1999-2009 is $(1.089 \pm 0.075) \times 10^{-2} \mathrm{yr}^{-1}$, resulting in a statistically significant difference in $\mathrm{CF}$ trends between these two periods of $(3.26 \pm 0.16) \times 10^{-2} \mathrm{yr}^{-1}$. Repeating the analysis using CFs derived from columns computed using the balloon-burst climatology, the trends are somewhat reduced, but remain statistically significant. Given our analysis, we recommend the following: (1) use of the balloon burst climatology is preferred to a constant mixing ratio assumption for determining total column ozone with sonde data; (2) if CFs are applied, their application should probably be restricted to altitudes above the tropopause; (3) only sondes that reach at least $32 \mathrm{~km}(10.5 \mathrm{hPa})$ before bursting should be used in data validation and/or ozone trend studies if the constant mixing ratio assumption is used to calculate the above burst column (as is the case for much of the data in the WOUDC archive). Using the balloon burst climatology, sondes that burst above $29 \mathrm{~km}(\sim 16 \mathrm{hPa})$, and perhaps lower, can be used; and (4) all ozone trend studies employing Japanese sonde data should be revisited after a careful examination of the impact of the $\mathrm{CF}$ on the calculated ozone trends.

\section{Introduction}

Ozonesondes have been a stalwart technology in atmospheric chemistry analyses for many decades. An early ozonesonde instrument is described in (Komhyr, 1969), with numerous follow-up studies examining the reliability, accuracy, and precision of ozonesonde data (e.g., Komhyr et al., 1995a,b; 
Smit et al., 2007). Ozonesonde data have also been used in numerous validation campaigns for satellite instruments, including the Stratospheric Aerosol and Gas Experiment (SAGE), SAGE II (e.g., Cunnold et al., 1989), SAGE III (e.g., Rault and Taha, 2007), the Halogen Occultation Experiment (HALOE) (e.g., Bruehl et al., 1996), the Microwave Limb Sounder (MLS) (e.g., Froidevaux et al., 1996; Jiang et al., 2007), the Tropospheric Emission Spectrometer (TES) (e.g, Nassar et al., 2008; Worden et al., 2007), the Atmospheric Infrared Sounder (AIRS) (e.g., Bian et al., 2007), the Global Ozone Monitoring Experiment (GOME) (e.g., Liu et al., 2006), the Scanning Imaging Absorption Spectrometer for Atmospheric Cartography (SCIAMACHY) (e.g., Brinksma et al., 2006) and the Ozone Mapping Instrument (OMI) (e.g., Kroon et al., 2011).

Integrated ozone profiles have been used to validate estimates of tropospheric column ozone (TCO) (e.g., Fishman et al., 1990; Thompson and Hudson, 1999; Ziemke et al., 2005; Osterman et al., 2008). Numerous studies have provided an analysis of trends in tropospheric ozone profiles (e.g., Hasebe and Yoshikura, 2006; Logan, 1994; Logan et al., 1999; Kivi et al., 2007; Krzyscin et al., 2007; Miller et al., 2006; Naja and Akimoto, 2004b; Oltmans et al., 2006; Logan, 1985). The reliability of the ozonesonde data sets is critical to our continued and developing understanding of ozone trends, transport, and tropospheric pollution studies.

In this paper, we examine carefully the ozonesonde data from four Japanese sounding stations: Sapporo, Tsukuba, Kagoshima, and Naha (see Table 1 for geographic and sampling information). These stations have provided long-term observations of ozone profiles since the late 1960's, with observations at Kagoshima ending in 2005 (see Table 1 for details). The Carbon Iodine (CI) electrochemical concentration cell (ECC) approach used by the Japanese stations is detailed in WMO (2011). In summary, this technology uses a single ECC with a platinum gauze cathode and activated carbon anode immersed in a potassium iodide solution. Phosphate buffers are added to keep the solution neutral, while potassium bromide is added to keep the solution from freezing. Ozone bubbled through the solution results in the redox-reaction with iodine. Contact with the platinum cathode causes the conversion of iodine back to iodide by the uptake of two electrons, which results in a reaction at the carbon anode. The electrical current so produced is directly related to the ozone concentration reported. This type of cell was first developed by Kobayashi and Toyama (1966) and has been used almost exclusively by the Japanese stations from the initiation of their observations until late 2009 at Sapporo and Tsukuba and late 2008 at Naha, at which point these stations switched to the two-cell ECC that is employed by most other ozonesonde stations around the world. All of the observations from the Kagoshima station used the CI ECC instruments.

All data presented in this paper have been retrieved from the World Ozone Ultraviolet Data Center (WOUDC, www.woudc.org) as submitted by the Japan Meteorological Agency (JMA), with file upload dates for all sites and date ranges listed in Table 2. Ozonesonde profiles in this archive most frequently apply correction factors (CF) to the profiles that results in better agreement between total columns computed from the sonde profiles and correlated ozone measurements (e.g., Dobson and Brewer spectrophotometers, satellite overpass data). Data in the header of the downloaded WOUDC files include an integrated column to the burst altitude, a total column amount, and a "correction code" to indicate the methodology employed to calculate the above balloon-burst altitude ozone column.

Two common methods for computing this above-burst column to "correct" the computed total columns are a constant mixing ratio (CMR) assumption and the stratospheric ozone climatology from the Solar Backscatter Ultraviolet (SBUV) instrument as derived originally by McPeters et al. (1997). The former approach assumes a constant ozone mixing ratio above the burst altitude of the balloon with a residual column ozone column (R) in Dobson Units (DU) given by

$R=7.892 \times \mathrm{O}_{3}$ (burst altitude)

where $\mathrm{O}_{3}$ is the partial pressure in milli-Pascals at the burst altitude (Hare et al., 2007). We note that the practice of using a CMR assumption for ozone above the balloon burst altitude appears to have been initiated in Dobson (1973). However, we also note in that paper, the use of the CMR assumption to compute the above balloon-burst column is endorsed only for those balloons that burst above $20 \mathrm{hPa}$ and is calculated only from the burst altitude up to $\sim 11 \mathrm{hPa}$ (or $\sim 30 \mathrm{~km}$ ).

The alternative approach employs the average monthly zonal mean ozone profile climatology in $10^{\circ}$ latitude bands as computed from SBUV data gathered from 1979-1990. This climatology can be interpolated in both latitude and time to match the specific latitude and date respectively of the ozonesonde launch. The residual ozone column above the balloon-burst height computed using this approach simply requires the integration of the SBUV climatological profile from the balloon burst altitude to the top of the atmosphere. McPeters and Labow (2012) have recently updated this climatology.

For the Japanese sounding data submitted to the WOUDC archive, the chosen method for calculating the residual column above the balloon burst altitude, as indicated in each WOUDC data file header, is the CMR assumption. The header also indicates the value of the $\mathrm{CF}$, the correlative observation type used to compute the CF, and whether or not the CF has been applied to the profile (in most cases, it has been applied).

The use of the CF with the sounding data may be warranted for several reasons. First, different versions of the mechanical pump have been used at different stations, and even at the same station during different periods of time. Studies such as the Jülich Ozone Sonde Intercomparison Experiments (JOSIE, e.g., Smit and Sträter, 2004) have 
Table 1. Information for the Japanese ozonesonde stations used in this study.

\begin{tabular}{|c|c|c|c|c|}
\hline Station & Latitude & Longitude & Date range & Sonde type \\
\hline Sapporo & $43.1^{\circ} \mathrm{N}$ & $141.3^{\circ} \mathrm{E}$ & $\begin{array}{l}\text { Jan 1990-Jul } 1997 \\
\text { Aug 1997-Nov } 2009 \\
\text { Dec 2009-present }\end{array}$ & $\begin{array}{l}\mathrm{KC}-79 \\
\mathrm{KC}-96 \\
\mathrm{ECC}\end{array}$ \\
\hline Tsukuba & $36.1^{\circ} \mathrm{N}$ & $140.1^{\circ} \mathrm{E}$ & $\begin{array}{l}\text { Jan 1990-May } 1997 \\
\text { June 1997-Nov } 2009 \\
\text { Dec 2009-present }\end{array}$ & $\begin{array}{l}\mathrm{KC}-79 \\
\mathrm{KC}-96 \\
\mathrm{ECC}\end{array}$ \\
\hline Kagoshima & $31.6^{\circ} \mathrm{N}$ & $130.6^{\circ} \mathrm{E}$ & $\begin{array}{l}\text { Jan 1990-Jul } 1997 \\
\text { Aug 1997-Mar } 2005\end{array}$ & $\begin{array}{l}\mathrm{KC}-79 \\
\mathrm{KC}-96\end{array}$ \\
\hline Naha & $26.2^{\circ} \mathrm{N}$ & $127.7^{\circ} \mathrm{E}$ & $\begin{array}{l}\text { Jan 1990-Jul } 1997 \\
\text { Aug 1997-Oct } 2008 \\
\text { Nov 2008-present }\end{array}$ & $\begin{array}{l}\mathrm{KC}-79 \\
\mathrm{KC}-96 \\
\mathrm{ECC}\end{array}$ \\
\hline
\end{tabular}

Table 2. Information on the files downloaded from the WOUDC in YYYY-MM-DD format. Ozonesonde data supplied by JMA.

\begin{tabular}{|c|c|c|c|c|c|c|c|c|}
\hline \multicolumn{3}{|c|}{ Sapporo } & \multicolumn{3}{|c|}{ Tsukuba } & \multicolumn{3}{|c|}{ Naha } \\
\hline $\begin{array}{l}\text { Earliest Flight } \\
\text { Date }\end{array}$ & $\begin{array}{l}\text { Latest Flight } \\
\text { Date }\end{array}$ & $\begin{array}{l}\text { WOUDC File } \\
\text { Creation Date }\end{array}$ & $\begin{array}{l}\text { Earliest Flight } \\
\text { Date }\end{array}$ & $\begin{array}{l}\text { Latest Flight } \\
\text { Date }\end{array}$ & $\begin{array}{l}\text { WOUDC File } \\
\text { Creation Date }\end{array}$ & $\begin{array}{l}\text { Earliest Flight } \\
\text { Date }\end{array}$ & $\begin{array}{l}\text { Latest Flight } \\
\text { Date }\end{array}$ & $\begin{array}{l}\text { WOUDC File } \\
\text { Creation Date }\end{array}$ \\
\hline 1990-01-17 & $1999-12-29$ & 2004-09-23 & 1990-01-03 & $1999-12-28$ & 2004-09-24 & 1990-01-17 & $1999-12-28$ & 2004-0924 \\
\hline 2000-01-05 & $2007-12-26$ & 2008-03-12 & 2000-01-05 & $2008-01-30$ & 2008-03-12 & 2000-01-06 & $2008-01-23$ & 2008-03-12 \\
\hline 2008-01-04 & 2009-02-09 & 2009-04-28 & 2008-02-07 & $2009-02-25$ & 2009-04-28 & 2008-02-04 & $2008-10-29$ & 2009-04-28 \\
\hline 2009-03-03 & $2009-03-25$ & $2009-05-20$ & 2009-03-04 & 2009-03-26 & $2009-05-20$ & 2008-11-13 & $2008-11-20$ & 2009-11-03 \\
\hline 2009-04-02 & 2009-04-30 & 2009-06-09 & 2009-04-01 & 2009-04-30 & 2009-06-10 & $2008-12-03$ & $2008-12-03$ & $2009-11-16$ \\
\hline 2009-05-07 & 2009-06-24 & 2009-08-09 & $2009-05-07$ & $2009-06-25$ & $2009-08-10$ & 2009-01-14 & $2009-01-28$ & $2009-11-03$ \\
\hline 2009-07-07 & $2009-07-30$ & $2009-08-30$ & 2009-07-01 & $2009-07-29$ & $2009-08-31$ & 2009-02-03 & 2009-02-03 & $2009-11-16$ \\
\hline 2009-08-04 & 2009-08-18 & 2009-10-05 & 2009-08-05 & $2009-08-26$ & $2009-10-05$ & 2009-02-10 & $2009-06-24$ & 2009-11-03 \\
\hline 2009-09-01 & 2009-09-30 & 2009-11-02 & 2009-09-02 & 2009-09-24 & 2009-11-02 & 2009-07-01 & 2009-07-01 & $2009-11-16$ \\
\hline 2009-10-07 & $2009-10-28$ & 2010-10-04 & 2009-10-01 & $2009-10-28$ & 2010-10-04 & 2009-07-08 & 2009-07-22 & 2009-11-03 \\
\hline 2009-11-12 & $2009-12-17$ & 2010-10-18 & 2009-11-12 & $2009-12-22$ & $2010-10-18$ & 2009-07-29 & 2009-08-12 & $2009-11-16$ \\
\hline 2010-01-04 & $2010-01-27$ & 2010-09-20 & 2010-01-15 & $2010-01-27$ & 2010-09-20 & $2009-08-26$ & 2009-09-30 & 2009-11-03 \\
\hline 2010-02-01 & $2010-02-24$ & $2010-09-27$ & 2010-02-03 & $2010-02-24$ & $2010-09-27$ & 2009-10-09 & $2009-10-28$ & 2010-10-04 \\
\hline 2010-03-04 & 2010-03-29 & 2010-06-14 & 2010-03-03 & 2010-03-31 & 2010-06-14 & 2009-11-04 & $2009-12-22$ & $2010-10-18$ \\
\hline 2010-04-05 & 2010-04-19 & $2010-06-16$ & 2010-04-08 & 2010-04-21 & $2010-06-16$ & 2010-01-07 & $2010-01-20$ & 2010-09-20 \\
\hline $2010-05-17$ & $2010-05-17$ & 2010-07-05 & 2010-05-06 & $2010-05-28$ & 2010-07-05 & 2010-02-02 & $2010-02-24$ & $2010-09-27$ \\
\hline 2010-06-10 & 2010-06-30 & $2010-07-27$ & 2010-06-03 & 2010-06-30 & $2010-07-27$ & 2010-03-03 & 2010-03-24 & 2010-06-14 \\
\hline 2010-07-15 & $2010-07-15$ & 2010-09-07 & 2010-07-08 & $2010-07-23$ & 2010-09-07 & 2010-04-08 & 2010-04-21 & 2010-06-16 \\
\hline 2010-08-02 & $2010-08-30$ & 2010-10-04 & 2010-08-04 & $2010-08-24$ & 2010-10-04 & 2010-05-05 & $2010-05-26$ & 2010-07-05 \\
\hline 2010-09-09 & 2010-09-30 & 2010-11-02 & 2010-09-01 & 2010-09-29 & 2010-11-02 & 2010-06-30 & $2010-06-30$ & $2010-07-27$ \\
\hline 2010-10-06 & $2010-10-27$ & 2010-11-29 & 2010-10-06 & $2010-10-27$ & 2010-11-29 & 2010-07-14 & 2010-07-21 & 2010-09-07 \\
\hline $2010-11-17$ & $2010-11-24$ & 2011-01-04 & 2010-11-04 & $2010-11-24$ & 2011-01-04 & 2010-08-04 & $2010-08-25$ & $2010-10-04$ \\
\hline $2010-12-02$ & $2010-12-27$ & 2011-01-31 & 2010-12-01 & $2010-12-22$ & 2011-01-31 & 2010-09-08 & 2010-09-22 & 2010-11-02 \\
\hline \multicolumn{3}{|c|}{ Kagoshima } & & & & 2010-10-06 & $2010-10-13$ & $2010-11-29$ \\
\hline $1990-01-17$ & $1999-12-22$ & 2004-09-24 & & & & 2010-11-04 & $2010-11-24$ & 2011-01-04 \\
\hline 2000-01-06 & $2005-03-30$ & 2008-03-12 & & & & 2010-12-01 & $2010-12-22$ & 2011-01-31 \\
\hline
\end{tabular}

demonstrated different responses with different pumps under the same conditions, resulting in uncorrected measurements that disagree with one another.

Second, it is well known that the efficiency of the pump changes as the pump moves into the very low pressure part of the profile in the stratosphere. Most stations do not test the performance of each and every pump before launch, but rather use a standard pump efficiency correction, first documented in Komhyr (1986). Since each pump performs somewhat differently, applying a $\mathrm{CF}$ to the stratospheric portion of the profile may compensate for the inaccuracies resulting from the use of the standard pump efficiency correction. The pumps typically perform well in the troposphere (the standard correction is 1.0172 at $100 \mathrm{hPa}$ or $\sim 16 \mathrm{~km}$ and is 1.000 at $300 \mathrm{hPa}$ or $\sim 8.5 \mathrm{~km}$ ), so applying the CF to the entire profile to correct for the inaccuracy of the standard pump correction approximation certainly is not warranted.

Third, the solutions used in the ECC(s) impact the ozone measurements, with recommended solutions documented for specific types of ozonesonde pumps in JOSIE 2009. Data from stations using solutions different than recommended can be corrected using transformation functions developed as 
part of the current Ozonesonde Data Quality Assessment activity led by Herman Smit on behalf of the SPARC-IGACOIOC Assessment of Past Changes in the Vertical Distribution of Ozone.

Fourth, the measurement of the pump temperature plays a critical role in the calculation of the partial pressure of ozone measurement:

$P_{\mathrm{O}_{3}}=\frac{R T_{\mathrm{P}}}{2 F\left(\eta_{C} \Phi_{\mathrm{P}}\right)}\left(I_{\mathrm{M}}-I_{\mathrm{B}}\right)$

where $P_{\mathrm{O}_{3}}$ is the partial pressure of ozone, $R$ is the Universal Gas Constant, $T_{\mathrm{P}}$ is the pump temperature, $F$ is Faraday's constant; $\eta_{C}$ is the conversion efficiency of the ozone sensor (usually nearly 1.0); $\Phi_{\mathrm{P}}$ is the gas volume flow rate through the pump; $I_{\mathrm{M}}$ is the measured intercell current; and $I_{\mathrm{B}}$ is the background intercell current.

Fifth and finally, the radiosonde technology employed over time and between stations has also varied. Pressure offsets and biases between such instruments can impact the altitudes at which ozone profile features appear as well as the calculated ozone mixing ratio based upon the partial pressure measurement above (this subject of pressure offsets will be presented in separate future paper, currently in preparation).

As can be seen, many factors can influence the reported ozone profiles. Of these factors, the flow rate, the pump temperature, the measured current, and the conversion efficiency may all contribute to offset errors in the ozone partial pressure. Application of a constant CF applied to the ozone profile may result in better agreement with other measures, a result that has motivated the use of CFs by ozonesonde stations before the submission of their data to international archives, as was the case for the Japanese data.

In the remainder of this paper, we examine in detail the impact of the $\mathrm{CF}$ as applied to the Japanese soundings in comparisons with satellite, surface monitor, and coincident profile data, particularly noting trends in the CF itself as well as trends in the agreement with the column and surface ozone readings. The final section offers some conclusions derived from this study as well as some recommendations for the use of CF data with ozonesonde profiles.

\section{Column measurements}

In this section, we investigate the need for a correction factor (CF) as determined through comparisons of integrated ozonesonde profiles with satellite overpass data. In addition, we compare the CFs computed with columns that use the CMR assumption for the above burst height column (as reported in the WOUDC data archive files) with the CFs we compute with columns that append the McPeters et al. (1997) balloon-burst climatology (BBC). Without the application of any $\mathrm{CFs}$, we find large $(\sim 5-10 \%)$ offsets in sonde columns as compared with satellite overpass data. Furthermore, we find trends in these offsets over the period of our study

\section{Japanese Sondes (1990 - 2009)}

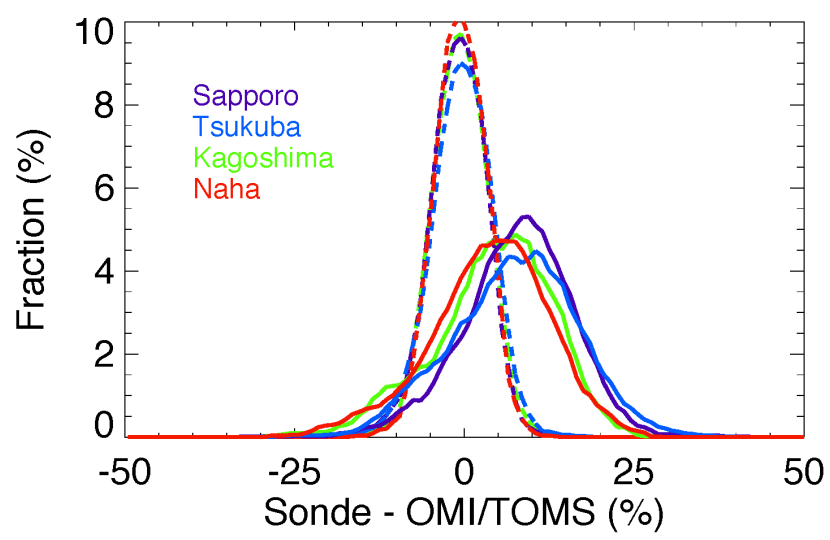

Fig. 1. A comparison of column ozone between integrated ozonesonde profiles from and the TOMS/OMI overpass data for the four Japanese stations. The thick lines represent data without the $\mathrm{CF}$, while the dashed lines represent the data multiplied by the correction factor $(\mathrm{CF})$ as applied and cited in the WOUDC data files. Kagoshima data cease in 2005.

(1990-2009). The columns computed with the BBC result in CFs nearer to 1.0, suggesting this approach is preferred, as we demonstrate below.

Figure 1 shows histograms of the total column ozone from the sonde data minus Total Ozone Mapping Spectrometer (TOMS, 1990-2004) or Ozone Mapping Instrument (OMI, 2004-2009) overpass columns as a percentage of the TOMS/OMI measurement for the four Japanese ozonesonde stations. The solid (dashed) lines represent the differences between the sonde columns without (with) the CF applied and the satellite columns (both the columns with and without the CFs applied appear in the header of the WOUDC data files). The sonde column with the $\mathrm{CF}$ is, by definition, the same as the correlative instrument column listed in the header of the same data file, as can be seen from the procedure used to calculate the CFs: (1) integrate the raw ozonesonde profiles from the surface to burst altitude without the CF applied; (2) add on an above burst height column based on a CMR assumption; (3) compare with the reference instrument (a ground-based Dobson instrument co-located at each ozonesonde station in the case of the Japanese sounding data); (4) the CF is the ratio of the reference instrument column to the sonde column. Throughout the remainder of this paper, we use the designation, "CF," when we refer to this approach.

For all four Japanese stations, the histograms in Fig. 1 for the TOMS/OMI column comparison data without the CF are shifted to values greater than 0 with rather broad offset distributions. Sapporo and Tsukuba show the largest offsets while Naha shows the smallest offset. The columns computed with the CFs applied at all four stations show much 
Table 3. Trends in the differences between sonde and satellite ozone columns, and the mean offsets in those column ozone differences (Japanese ozonesonde columns minus TOMS/OMI columns) for the period 1990-2009 ("Overall") as computed with and without the CF applied. The calculations are based only on those sondes that reach a minimum altitude of $32 \mathrm{~km}(10.5 \mathrm{hPa})$ before bursting. The numbers in parenthesis in this and the following tables represent one standard deviations.

\begin{tabular}{|c|c|c|c|c|c|c|}
\hline \multirow{2}{*}{$\begin{array}{l}\text { No CF } \\
\text { Station }\end{array}$} & \multicolumn{2}{|c|}{ Overall } & \multicolumn{2}{|c|}{ 1990-1999 } & \multicolumn{2}{|c|}{ 2000-2009 } \\
\hline & Offset (\%) & Trend (\%/decade) & Offset $(\%)$ & Trend (\%/decade) & Offset (\%) & Trend (\%/decade) \\
\hline Sapporo & $7.8(7.9)$ & $2.36(0.61)$ & $5.9(8.3)$ & $11.1(1.7)$ & $8.8(7.4)$ & $-8.7(1.4)$ \\
\hline Tsukuba & $7.4(9.0)$ & $3.73(0.53)$ & $5.6(10.3)$ & $18.8(1.4)$ & $9.2(7.4)$ & $-12.4(1.1)$ \\
\hline Kagoshima* & $4.2(8.4)$ & $5.59(0.84)$ & $3.0(9.5)$ & $15.7(1.8)$ & $5.5(7.0)$ & $-8.3(2.8)$ \\
\hline Naha & $3.7(8.4)$ & $2.47(0.60)$ & $3.1(9.9)$ & $16.7(1.7)$ & $4.2(7.1)$ & $-4.5(1.4)$ \\
\hline Overall & $6.1(8.7)$ & $3.47(0.31)$ & $4.5(9.7)$ & $16.00(0.82)$ & $7.3(7.6)$ & $-7.75(0.74)$ \\
\hline $\mathrm{w} / \mathrm{CF}$ & \multicolumn{2}{|c|}{ Overall } & \multicolumn{2}{|c|}{ 1990-1999 } & \multicolumn{2}{|c|}{ 2000-2009 } \\
\hline Station & Offset (\%) & Trend (\%/decade) & Offset (\%) & Trend (\%/decade) & Offset (\%) & Trend (\%/decade) \\
\hline Sapporo & $-0.9(3.2)$ & $1.23(0.24)$ & $-1.4(3.0)$ & $-0.10(0.67)$ & $-0.5(3.2)$ & $1.23(0.61)$ \\
\hline Tsukuba & $-0.3(3.6)$ & $1.69(0.21)$ & $-1.3(4.0)$ & $-0.33(0.66)$ & $0.5(3.0)$ & $1.69(0.48)$ \\
\hline Kagoshima* & $-0.7(3.2)$ & $-0.09(0.34)$ & $-0.4(3.3)$ & $1.03(0.71)$ & $-0.9(3.1)$ & $-0.09(1.28)$ \\
\hline Naha & $-0.6(2.7)$ & $2.19(0.17)$ & $-2.0(2.4)$ & $0.96(0.48)$ & $0.4(2.5)$ & $2.19(0.48)$ \\
\hline Overall & $-0.7(3.3)$ & $1.49(0.12)$ & $-1.4(3.5)$ & $0.34(0.34)$ & $-0.1(3.1)$ & $3.07(0.30)$ \\
\hline
\end{tabular}

*For Kagohsima station, the data record ends in 2005.
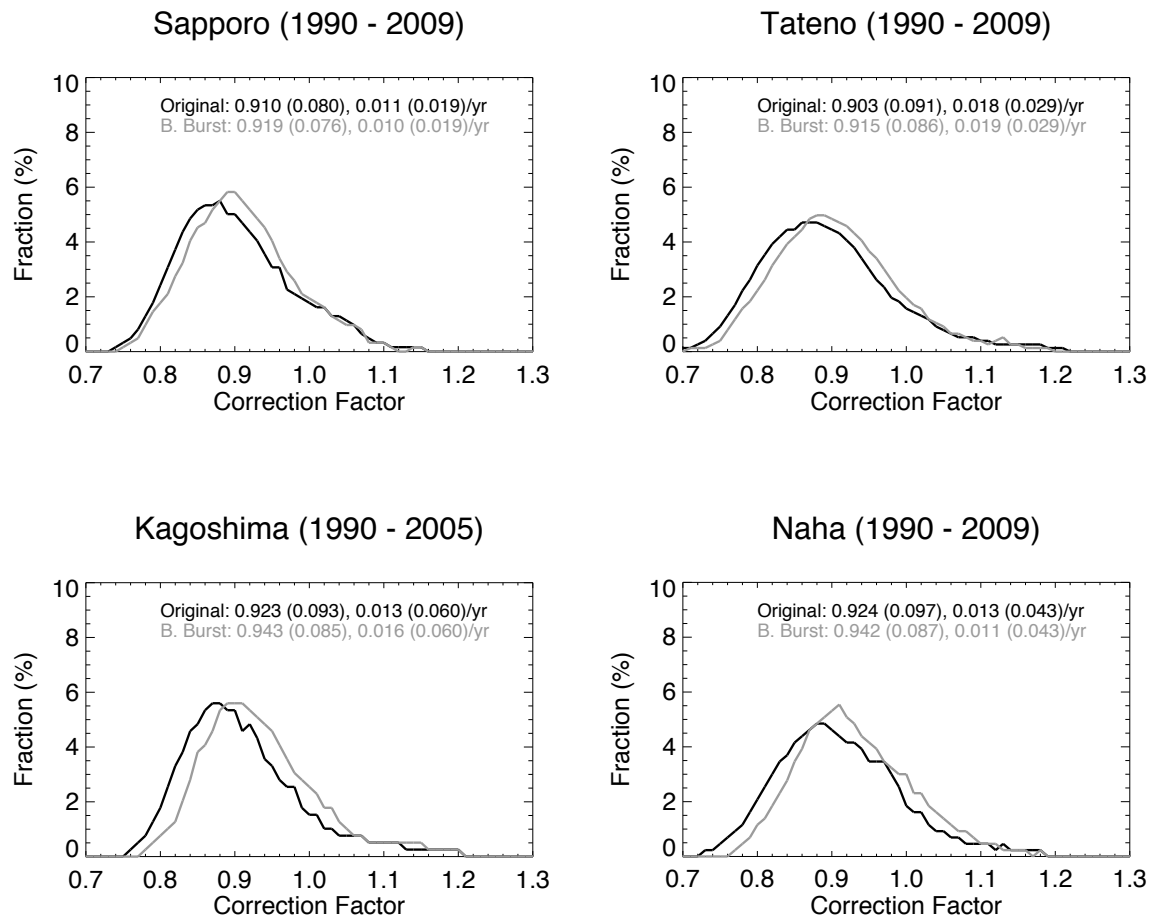

Fig. 2. Histograms showing a comparison of the corrections factors applied and listed in the WOUDC data files with those calculated in this study using a balloon-burst climatology. For all stations, the balloon-burst correction factors are nearer to 1.0. The numbers in parenthesis represent one standard deviations. 
narrower distributions that are similar to one another, with slight negative offsets. The better agreement between the ozonesonde columns with the $\mathrm{CF}$ and the satellite data is not surprising given the documented good agreement between ground-based Dobson instruments and satellite overpass data (McPeters and Labow, 1996; Balis et al., 2007; Fioletov et al., 2008).

Table 3 describes the statistical characteristics of the histogram data depicted in Fig. 1. We note that the standard deviations (in parentheses in the Table) are similar for all four sites, although the offsets vary. For the columns without the CFs applied, the offsets range from a low of $(3.7 \pm 8.4) \%$ at Naha to a high of $(7.8 \pm 7.9) \%$ at Sapporo, with an overall mean over the four sites of $(6.1 \pm 8.7) \%$. With the CFs, the offsets range from $(-0.3 \pm 3.6) \%$ at Tsukuba to $(-0.9 \pm$ $3.2) \%$ at Sapporo, with a mean of $(-0.7 \pm 3.3) \%$. The data suggest that integrated ozonesonde profiles without CFs applied result in much larger columns than found from either the ground-based or satellite column observations.

The data in Table 3 also reveal trends in the differences between the sonde and satellite columns for the period 1990-2009 (1990-2005 for Kagoshima). Without the $\mathrm{CF}$, these trends range from $(2.36 \pm 0.61) \% /$ decade at Sapporo to $(5.59 \pm 0.84) \% /$ decade at Kagoshima, with a mean trend over the 4 sites of $(3.47 \pm 0.31) \% /$ decade. With the $\mathrm{CF}$, the trends are smaller but generally significant, ranging from the insignificant $(-0.09 \pm 0.34) \% /$ decade at Kagoshima to $(2.19 \pm 0.17) \% /$ decade at Naha, with a mean of $(1.49 \pm 0.12) \% / d e c a d e$. The reason for the trends in the offsets is unknown, although we investigate several possibilities below.

Finally, Table 3 divides the period 1990-2009 in half, computing offsets and trends in the column differences for the sub-periods of 1990-1999 and 2000-2009 (the justification for the separation of the analysis into these two subperiods lies in the trends in the CFs themselves, discussed below). For the sonde columns without the $\mathrm{CF}$, we see the offsets are generally not statistically significantly different from 0 or each other during either sub-period. The trends in the offsets without the CFs, however, show a statistically significant difference between the two sub-periods at every station and overall, with the overall trend during the 1990-1999 period being $(16.00 \pm 0.82) \% /$ decade and during the 2000 2009 period being $(-7.75 \pm 0.74) \% /$ decade, for a difference (latter minus former) of $(-23.8 \pm 1.1) \% /$ decade.

The sonde columns with the $\mathrm{CF}$ again shown no statistically significant difference at any station during either period or between periods, nor do the overall offsets. The trends in the offsets, however, do show a statistically significant difference between the former and latter periods at all stations except Kagoshima (where the record ends in 2005). Overall, the trend shifts from $(0.34 \pm 0.34) \% /$ decade during the 1990-1999 period to $(3.07 \pm 0.30) \% /$ decade, with a difference (latter minus former) of $(2.73 \pm 0.45) \% /$ decade.
Figure 2 provides a comparison of the histograms of the $\mathrm{CFs}$ at each ozonesonde station as given in the WOUDC file headers (which use the CMR assumption) with those we compute by integrating the ozonesonde profiles and adding the BBC column adjustment (McPeters et al., 1997). The Dobson columns are divided by these "balloon-burst" columns to get the correction factors, which we label as " $\mathrm{CF}_{\mathrm{BB}}$ " hereafter. The $\mathrm{CF}_{\mathrm{BB}}$ are otherwise computed in exactly the same way as the standard CFs, as described above. In each case, we see the distributions are shifted to values further from and less than 1.0 (where 1.0 indicates perfect agreement with the ground-based column measurement), though this shift is lessened when the balloon-burst approach is applied. Based on this analysis, therefore, we recommend using the BBC for computing ozonesonde columns.

Figure $3 \mathrm{a}$ shows the mean CFs at each ozonesonde station as a function of burst altitude (computed from the burst pressures) divided into 2-km increments. The figure also separates the 1990-1997 data (red) from the 1997-2009 data (blue). During the former period, the instruments were KC79 type sondes, while during the latter period, they were KC-96 (except Naha, which in addition to this switch also switched from KC-96 to ECC sondes in 2008 - see Table 1). At all four stations, lower burst altitudes result in larger CFs. The CFs are typically lower for the 1997-2009 period as compared to the 1990-1997 period except for the Naha station, where the values are comparable. CFs for burst altitudes $>32 \mathrm{~km}$ appear nearly constant.

We note that Logan et al. (1999) used a burst altitude criteria of $16 \mathrm{hPa}(\sim 29 \mathrm{~km})$ in selecting sondes for use in their trend calculations using three Japanese stations (Sapporo, Tateno/Tsukuba, and Kagoshima) from late 1968/early 1969-1996. Based on our Fig. 3a for data from 1990-1997, it appears that the CFs at $29 \mathrm{~km}$ are slightly higher than those $>32 \mathrm{~km}(10.5 \mathrm{hPa})$, although not by a statistically significant amount. For most of the remainder of this study, therefore, we present only ozonesonde data resulting from flights with burst altitudes $>32 \mathrm{~km}$. Furthermore, given the dependence of the CF on burst altitude, we recommend that satellite validation work use only those ozonesonde profiles that attain altitudes of at least $32 \mathrm{~km}(10.5 \mathrm{hPa})$, if those ozonesondes have used a CMR assumption to compute the above burst altitude column amount.

Figure $3 \mathrm{~b}$ shows the $\mathrm{CF}_{\mathrm{BB}} \mathrm{S}$ as a function of altitude using ozonesonde columns computed with BBC (McPeters et al., 1997). In this case, we see a result much more consistent with the Logan et al. (1999) recommendation: above $29 \mathrm{~km}$ ( $\sim 16 \mathrm{hPa}$ ), the $\mathrm{CF}_{\mathrm{BB}} \mathrm{S}$ appear fairly consistent. One might argue that the $\mathrm{BBC}$ allows for the use of sondes that burst at even lower altitudes in validation studies or for comparison with co-located column observations.

We further examine the differences in $\mathrm{CFs}$ between the KC-79 and KC-96 sondes as compared with the findings from the JOSIE 2000 (Smit and Sträter, 2004) and JOSIE 1996 (Smit and Kley, 1998). JOSIE 2000 found that the 
Sapporo Soundings

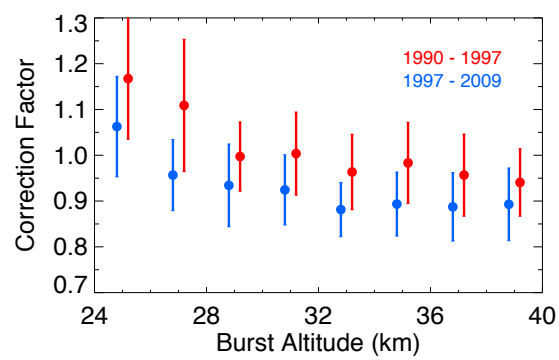

Kagoshima Soundings

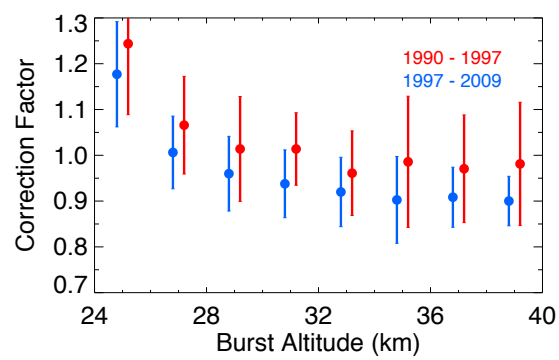

Tsukuba Soundings

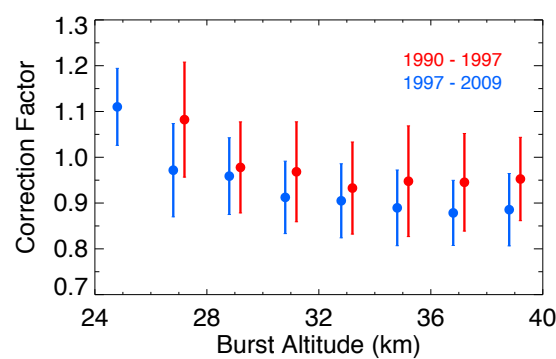

Naha Soundings

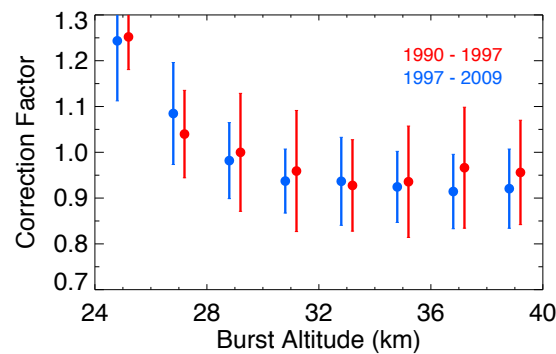

Fig. 3a. CFs reported in the WOUDC data files as a function of burst altitude for ozonesonde profiles and columns at the Japanese stations. Data are divided in 2-km bins by burst altitude and divided temporally from 1990-1997 (KC-79 sondes) and 1997-2009 (KC-96 sondes). The error bars represent one standard deviations.
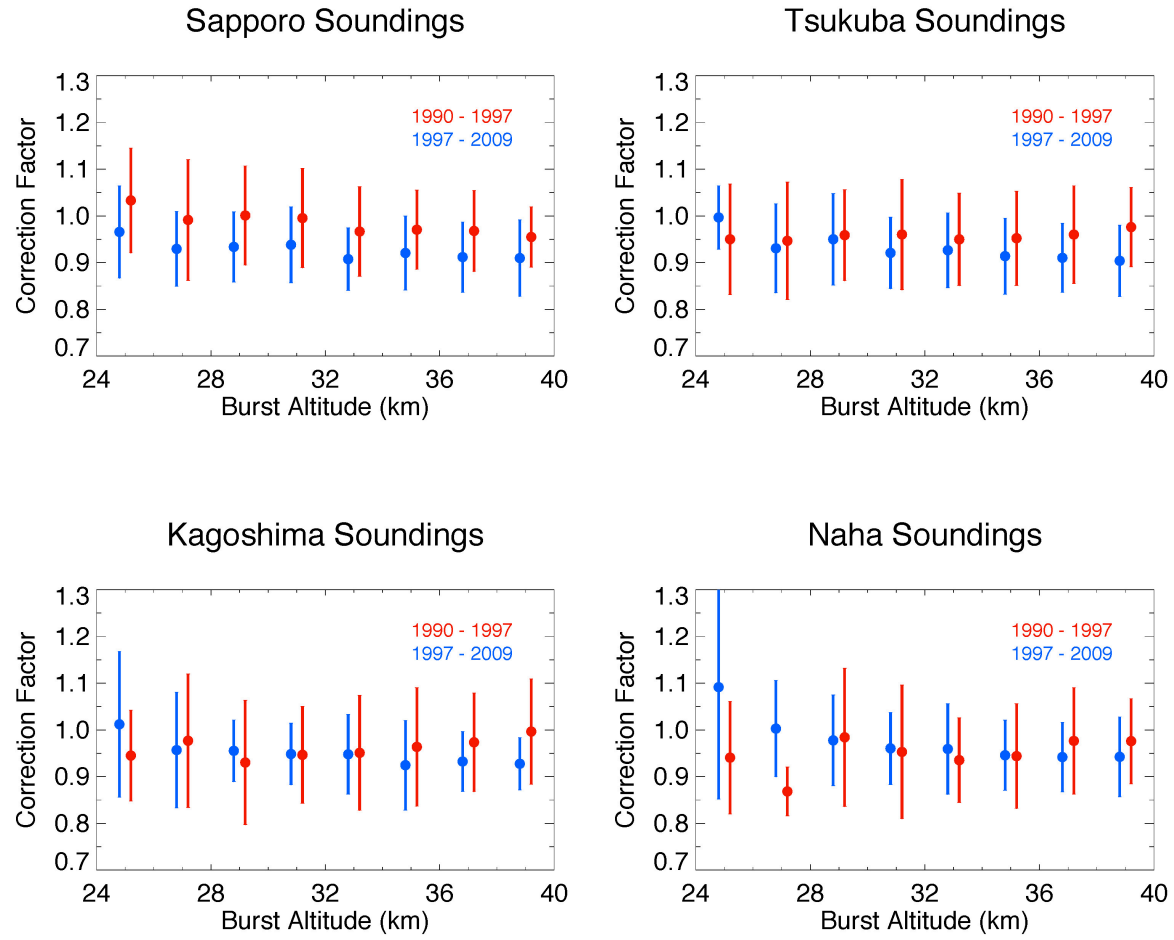

Fig. 3b. As in Fig. 3a, but the CFs are calculated on columns computed using the balloon burst climatology to compute the above-burst altitude columns. 
Sapporo Soundings

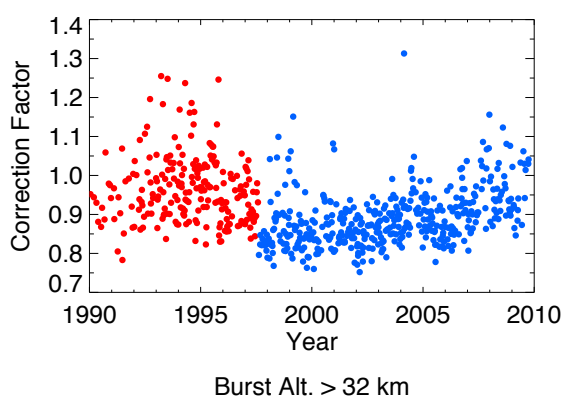

Kagoshima Soundings

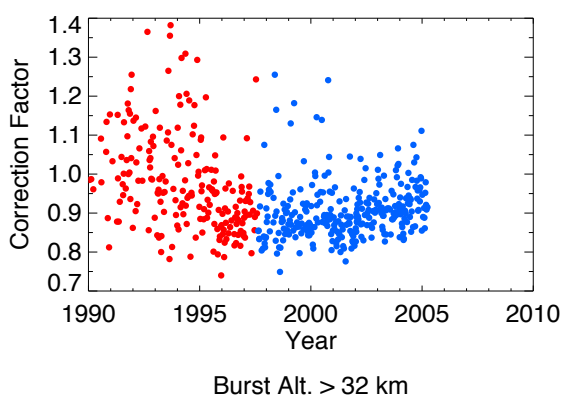

Tsukuba Soundings

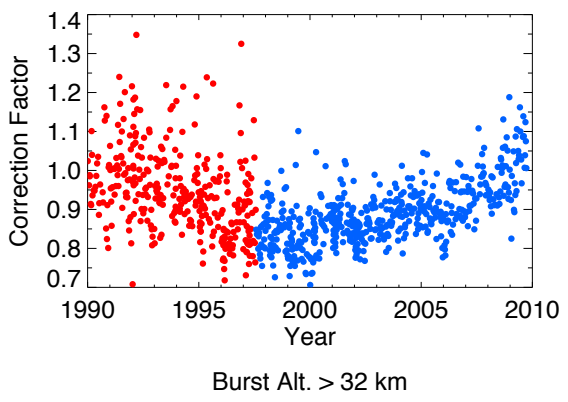

Naha Soundings

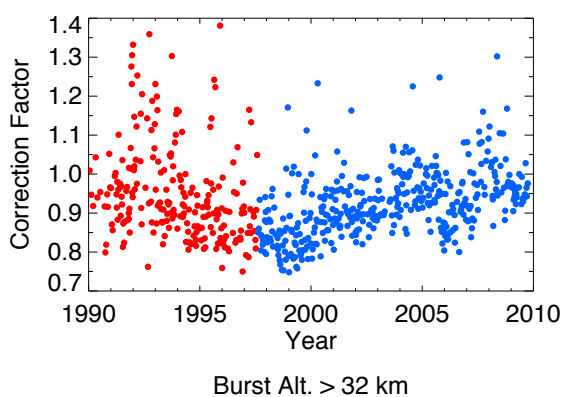

Fig. 4. CFs reported in the WOUDC data files as a function of time for all soundings from the Japanese stations that reach a burst altitude of at least $32 \mathrm{~km}(10.5 \mathrm{hPa})$. For Sapporo, Kagoshima, and Naha, ozonesondes changed from KC-79 to KC-96 in August 1997, while for Tsukuba, the change occurred in June 1997. CFs reached a minimum around the time of the change, were trending downward before the change, and have trended upward since the change at all four stations. See also Table 4 for calculations of these trends.

KC-96 sondes performed better in a controlled environmental chamber simulation than did the KC-79 sondes, with a resultant mean $\mathrm{CF}$ of $0.96 \pm 0.02$ for the $\mathrm{KC}-96$ versus the $0.91 \pm 0.10$ found in JOSIE 1996 for the KC-79 sondes. Looking at the CFs for the Japanese sondes that were flown, we find a mean of $0.962 \pm 0.055$ for the KC-79 sondes (1979-1997) and a mean of $0.901 \pm 0.038$ for the KC-96 sondes (1998-2008), suggesting that the KC-96 sondes that were flown have uncorrected columns with larger differences from the correlative measurements than the KC-79 sondes, a result different from JOSIE. The smaller scatter in the KC-96 data, as indicated by the smaller standard deviation, is consistent with the finding of JOSIE 2000, but the mean CF value for the KC-96 sondes is further from 1.0 than the KC-79 data. Even if we look at the CFs just in the years of the JOSIE studies, we find a mean CF in 1996 of $0.890 \pm 0.040$ for the KC79 sondes and a mean CF in 2000 of $0.884 \pm 0.039$ for the KC-96 sondes, a result suggesting essentially no difference between the performances of the two types of sondes. The explanation for the differences between the CF results with the flown sondes and those of the JOSIE data is unknown at present but probably warrants further investigation.

Figure 4 shows the CFs as a function of time at all four ozonesonde stations for only those flights with burst altitudes $>32 \mathrm{~km}$. The data are divided into two groups: those prior to August 1997 (red, KC-79 sondes) and those since August 2007 (blue, KC-96 sondes). We note that the scatter in the CFs decreases after the switch from KC-79 to KC-96. Table $4 \mathrm{a}$ provides the $\mathrm{CF}$ trends and their uncertainties. All four stations show statistically significant decreases in the CF values as a function of time from 19901997. The mean trend over all four stations during this period is $(-1.80 \pm 0.16) \times 10^{-2} \mathrm{yr}^{-1}$. Since 1999 , all four stations show increasing $\mathrm{CFs}$, with a mean increase of the $\mathrm{CF}$ of $(1.089 \pm 0.075) \times 10^{-2} \mathrm{yr}^{-1}$. The mean difference in these trends (latter period minus former period) is a statistically significant $(2.89 \pm 0.18) \times 10^{-2} \mathrm{yr}^{-1}$.

We repeated this analysis with the $\mathrm{CF}_{\mathrm{BB}}$ data. The analog to Fig. 4 with the $\mathrm{CF}_{\mathrm{BB}} \mathrm{S}$ as a function of time (not shown) is very similar in appearance. Table $4 \mathrm{~b}$ provides the $\mathrm{CF}_{\mathrm{BB}}$ trends and their uncertainties. We see that overall, while the trends are somewhat smaller in magnitude, they remain statistically significantly different from 0 in all cases. It is clear from this analysis that the method used to calculate the above-burst column is not responsible for the trends in the CFs observed.

Figure 5 shows the annual mean $\mathrm{CFs}$ at each of the Japanese stations using the data in Fig. 4. We can see that the trend toward CF values further away from and below 1.0 begins $\sim 1993$, about two years after the Mt. Pinatubo 


\section{Japanese Ozonesonde Stations}

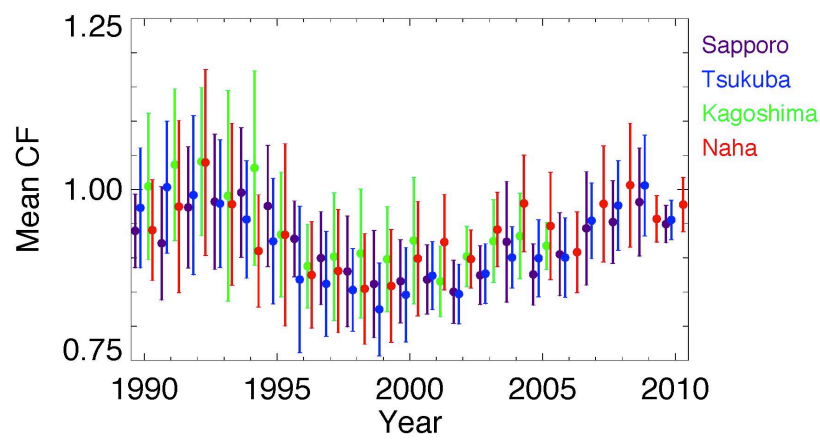

Fig. 5. Annual mean CFs for the data plotted in Fig. 4, with slight horizontal offsets for each station for clarity. The error bars represent one standard deviations.

eruption, with a recovery toward CFs of nearer 1.0 beginning $\sim 1999$. Table 4a,b also shows calculated trends in the CFs $\left(\mathrm{CF}_{\mathrm{BB}} \mathrm{S}\right)$ at the four stations divided into the two periods that appear to have consistent trends: 1993-1999 and 1999-2009. Table 4a reveals a statistically significant change in CF trends between these two periods, with an overall negative trend of $(-2.18 \pm 0.14) \times 10^{-2} \mathrm{yr}^{-1}$ during the former period, an overall positive trend of $(1.089 \pm 0.075) \times 10^{-2} \mathrm{yr}^{-1}$, and a statistically significant difference in the $\mathrm{CF}$ trends of $(3.26 \pm 0.16) \times 10^{-2} \mathrm{yr}^{-1}$. The trends in the $\mathrm{CF}_{\mathrm{BB}} \mathrm{S}$ (see Table $4 \mathrm{~b}$ ) tend to be somewhat smaller, but remain statistically significantly different from 0 . Again, the cause of these trends has yet to be determined.

Previous works have alluded to the potential problems caused by trends in CFs. The analysis shown in Fig. 1 in Logan et al. (1999) shows CFs (as found in the WOUDC data file headers) for Tateno (Tsukuba) sonde launches from 1970-1996. It is apparent from their Fig. 1 that the CFs were decreasing at the end of the time series, after $\sim 1993$, as seen more clearly in our Fig. 4. Table 4 in Logan et al. (1999) summarizes trend analyses in \%/decade for the periods 1970-1996 and 1980-1996. They found no statistically significant trends in the CFs at Sapporo or Kagoshima, but statistically significant negative $\mathrm{CF}$ trends of $-1.3 \pm 0.9$ or $-3.3 \pm 1.7 \% /$ decade for the two analysis periods respectively at Tateno (Tsukuba). Converting our results in Table 4 to the same units, we find a trend in the CF at Tsukuba of $\sim-27 \pm 3 \%$ /decade for the 1993-1999 period and of $\sim+18 \pm 1 \% /$ decade for the 1999-2009 period, much larger and more alarming than those found in Logan et al. (1999). We note, however, that the trend computed from 1990-2009 was only $\sim-1.0 \pm 0.5 \% /$ decade. The CFs at the end of the record nearly had recovered to their values at the beginning. The portion of the record analyzed in their paper showed a great deal more consistency in the CFs at Tsukuba from 1980-1992, with only the last few years of their analysis including the period with the strong trend noted in our Fig. 4.
They also used a lower burst altitude exclusion criterion $(16 \mathrm{hPa})$ than recommended in our study, and they excluded any sonde profile associated with a $\mathrm{CF}<0.8$ or $\mathrm{CF}>1.2$. As seen in our Fig. 4, the latter criterion excludes very few profiles before 1995. However, given the real trend seen in the CF data in the mid 1990s, more profiles report CFs at or less than 0.8, particularly during the 1997-2009 time period. Such profiles would be excluded from the Logan et al. (1999) analyses, but probably should not be, since the entire data set appears to be drifting toward CFs further from but less than 1.0. We suggest an altered exclusion criterion: rather than using the absolute difference between the $\mathrm{CF}$ and 1.0, use the difference between the $\mathrm{CF}$ and a running mean $\mathrm{CF}$ (smoothed $\mathrm{CF}$ with time) of more than two standard deviations in the period extending from 6 months prior to 6 months after the profile in question.

Miller et al. (2006) examined ozone profile trends using WOUDC data from 12 ozonesonde stations in the Northern Hemisphere. In their study, they exclude any soundings with a $\mathrm{CF}<0.9$ or $\mathrm{CF}>1.15$, a tighter criteria than (Logan et al., 1999), and one that becomes especially problematic from 1993-2008 for the Japanese sounding data. They note a statistically significant change in the ozone trend starting around 1996, nearly the same time the Japanese stations switched from KC-79 to KC-96 ozonesondes (Summer 1997) and corresponding to the minimum CFs in the 1990-2009 record examined in our paper. Miller et al. (2006) excluded the two years after the eruption of Mt. Pinatubo from their trend calculations. It is unclear the extent to which their results would change if the exclusion criterion based on the CFs was changed or the CFs not applied at all.

Solomon et al. (1998) discuss the impacts on stratospheric chemistry from the material injected into the upper troposphere and lower stratosphere by the eruption of Mt. Pinatubo (June 1991). They found decreases in ozone at Northern mid-latitudes $\left(40^{\circ}-60^{\circ} \mathrm{N}\right)$ as a result of heterogeneous chlorine chemistry, with a recovery by March of 1996. Keim et al. (1996) report significant reductions in the $\mathrm{NO}_{\mathrm{x}} / \mathrm{NO}_{\mathrm{y}}$ ratio near the mid-latitude tropopause as measured by the NASA ER-2 high-altitude aircraft during the April 1993 Stratospheric Photochemistry, Aerosols, and Dynamics Expedition (SPADE), again the result of heterogeneous reactions with chlorine species on Pinatubo aerosols. An outstanding question is, what if any impact the volcanic effluence and the resulting altered chemistry might have had on the reactions in the carbon-iodine sondes used by the Japanese stations? We have examined ozonesonde data from 9 other stations in the WOUDC database that use the Brewer-Mast and ECC approach. None exhibit similar trends in the associated CFs in their header of the data files at the WOUDC as found for the Japanese sondes.

The fact that the CFs show trends with time is of some concern. Caution is recommended if the ozonesonde data is to be used in trend calculations of ozone profile shapes, tropospheric columns, and/or stratospheric columns (Logan, 1994, 
Table 4a. Trends in the CFs for the Japanese ozonesonde stations. The calculations are based only on those sondes that reach a minimum altitude of $32 \mathrm{~km}(10.5 \mathrm{hPa})$ before bursting. The "Delta" column represents the difference in the trends of the 1999-2009 period and the 1993-1999 period. Numbers in parentheses represent one standard deviation uncertainties.

\begin{tabular}{lrrrrr}
\hline Site & & $\begin{array}{r}(\mathrm{KC}-79) \\
1990-1997\end{array}$ & $\begin{array}{r}\text { (KC-96) } \\
1993-1999\end{array}$ & $\begin{array}{r}1999-2009 \\
\left(10^{-2} \mathrm{yr}^{-1}\right)\end{array}$ & $\begin{array}{r}\text { Delta } \\
\left(10^{-2} \mathrm{yr}^{-1}\right)\end{array}$ \\
\hline Sapporo & $-0.198(0.058)$ & $-0.76(0.30)$ & $-2.43(0.25)$ & $1.14(0.11)$ & $3.57(0.27)$ \\
Tsukuba & $-0.089(0.053)$ & $-2.15(0.22)$ & -2.45 & $1.62(0.084)$ & $4.07(0.25)$ \\
Kagoshima & $-0.85(0.10)^{*}$ & $-2.50(0.37)$ & $-2.02(0.34)$ & $0.59(0.24)^{*}$ & $2.61(0.42)$ \\
Naha & $0.084(0.065)$ & $-1.77(0.34)$ & $-1.84(0.30)$ & $1.02(0.12)$ & $2.81(0.32)$ \\
\hline Overall & $\mathbf{- 0 . 2 6 4 ( 0 . 0 3 6 )}$ & $\mathbf{- 1 . 8 0}(\mathbf{0 . 1 6})$ & $-2.18(0.14)$ & $\mathbf{1 . 0 8 9}(\mathbf{0 . 0 7 5})$ & $\mathbf{3 . 2 6}(\mathbf{0 . 1 6})$ \\
\hline
\end{tabular}

*for Kagohsima station, the data record ends in 2005.

Table 4b. As in Table 4a, but using the balloon burst climatology for the above burst altitude column.

\begin{tabular}{|c|c|c|c|c|c|}
\hline Site & $\begin{array}{r}1990-2010 \\
\left(10^{-2} \mathrm{yr}^{-1}\right)\end{array}$ & $\begin{array}{r}(\mathrm{KC}-79) \\
1990-1997 \\
\left(10^{-2} \mathrm{yr}^{-1}\right)\end{array}$ & $\begin{array}{r}1993-1999 \\
\left(10^{-2} \mathrm{yr}^{-1}\right)\end{array}$ & $\begin{array}{r}(\mathrm{KC}-96) \\
1999-2009 \\
\left(10^{-2} \mathrm{yr}^{-1}\right)\end{array}$ & $\begin{array}{r}\text { Delta } \\
\left(10^{-2} \mathrm{yr}^{-1}\right)\end{array}$ \\
\hline Sapporo & $-0.136(0.049)$ & $-0.71(0.23)$ & $-1.76(0.22)$ & $0.94(0.10)$ & $2.69(0.24)$ \\
\hline Tsukuba & $-0.050(0.045)$ & $-1.89(0.18)$ & $-1.86(0.20)$ & $1.338(0.077)$ & $3.19(0.22)$ \\
\hline Kagoshima & $-0.596(0.085)^{*}$ & $-2.13(0.28)$ & -1.43 & $0.66(0.21)^{*}$ & $2.08(0.35)$ \\
\hline Naha & $0.025(0.053)$ & $-1.41(0.26)$ & $-1.30(0.24)$ & $0.57(0.11)$ & $1.87(0.27)$ \\
\hline Overall & $-0.190(0.030)$ & $-1.54(0.12)$ & $-1.59(0.12)$ & $0.874(0.067)$ & $2.45(0.14)$ \\
\hline
\end{tabular}

1985; Miller et al., 1995). Below, we comment on a few such studies that may have seen impacts from the trends in CFs at the Japanese stations.

Ziemke et al. (2005) found their tropospheric column ozone computed with the cloud slicing technique from Version 8 TOMS data exceeded that found by integrating tropospheric profiles at Kagoshima and Naha. As we can see by examining Fig. 4, both stations have CFs $<1.0$, meaning that the ozone columns computed from the sounding data are less than the uncorrected tropospheric columns. Thus, the CFs may explain, at least partially, the bias observed in Ziemke et al. (2005).

Oltmans et al. (2006) examined ozone profile trends for stations with data at the WOUDC. In particular, they found statistically significant positive trends below $300 \mathrm{hPa}$ for the three Japanese stations (Sapporo, Tsukuba, and Kagoshima) from 1970-2004, but negative trends below $700 \mathrm{hPa}$ from 1990-2004 at Naha. The authors also report that since the early 1990's, the tropospheric trends have been negative at all four of these stations, despite growing emissions from China that probably should have led to increased ozone transport to Japan. Based on the analysis presented here, at least part of the explanation lies in the fact that the CFs were trending downward from 1993-1999, resulting in tropospheric values that were smaller with time. Despite the increasing trend in the CFs following 1999, the values by 2004 had not yet re- covered to those seen in 1993, by which time the downward trend in CFs at the Japanese stations was clearly underway.

Hasebe and Yoshikura (2006) examined ozone trends using the data from the Japanese sounding stations for the periods 1968-1975 and 1990-2002 and a potential temperature/equivalent latitude analysis. They found losses of 5$20 \%$, mainly in the midlatitude stratosphere and of 30-50\% in the Spring season in the lower stratosphere, with negative trends from the former to the latter analysis period throughout the profile (their Fig. 3). In Table 5, we show the mean and one standard deviation values for the CFs at each of the three stations used in their analysis for each of the two periods. While none of the differences between the CFs at any of the stations is statistically significant, both Sapporo and Tsukuba show a trend toward smaller CF values, which would lead to lower ozone amounts. No trend is apparent at Kagoshima when examined over the entire period, but recall that trends in the CFs during the latter period are found at all three stations. Thus it remains an open question how much of the ozone profile trends reported in .Hasebe and Yoshikura (2006) are real and how much can be attributed solely to the trends in the CFs.

Finally, Hayashida et al. (2008) examined the agreement between GOME tropospheric ozone columns and the integrated Japanese sonde columns from 1996-2003 with the CFs applied. They found generally good agreement between the two instruments throughout this analysis period, although 
Table 5. Comparison of CFs at three Japanese stations for the periods 1968-1975 and 1990-2002, after (Hasebe and Yoshikura, 2006).

\begin{tabular}{lrr}
\hline Station & CFs 1968-1975 & CFs 1990-2002 \\
\hline Sapporo & $0.97(0.11)$ & $0.92(0.09)$ \\
Tsukuba & $0.97(0.11)$ & $0.90(0.10)$ \\
Kagoshima & $0.94(0.14)$ & $0.94(0.11)$ \\
\hline
\end{tabular}

their Fig. 2 suggests that the tropospheric sonde columns were typically less than those determined from GOME, and their data show no discernable trends in the differences between them, as might be expected from our analysis. The former result is consistent with the fact that the Japanese sonde profiles have been multiplied by CFs of less than 1.0, which suggests that the application of the CFs are not appropriate for the tropospheric column computed from ozonesonde data.

Since the greatest uncertainties in the ozonesonde profiles arise in the stratospheric portion of the data as a result of pump inefficiencies in the low pressure, low temperature environment at and above the tropopause, it may be necessary only to apply CFs to this portion of the profile (see Sect. 4 below). Application of the CFs to the tropospheric portions, however, may not be justified (see Sects. 3 and 4 below). For example, the study of Naja and Akimoto (2004) computed tropospheric trends after removing the CFs from the tropospheric portion of the ozone profiles. This approach is the one we would endorse for all tropospheric trend studies. In fact, this approach is also the one recommended in the SPARCIOC-GAW Report (1998, see pa. 170, second paragraph).

\section{Surface measurements}

In this section, we investigate the need for a $\mathrm{CF}$ as determined through comparisons of ozonesonde data gathered in the lowest $100 \mathrm{~m}$ above the surface of each flight with hourly averaged data from surface monitors near the launch sites. Ideally each ozonesonde station would have its own ozone monitor so that pre-launch ozone measurements from the sondes could be validated against the ground-based monitors.

We use the long-term station database (available online at: http://www.nies.go.jp/igreen/td_disp.html) as a source for the surface monitor data, and note that most of the Japanese stations actually report "oxidant" mixing ratios, which they define to be ozone and peroxylacetyl nitrates, but not $\mathrm{NO}_{2}$. The fraction of PAN in $\mathrm{O}_{\mathrm{x}}$ is negligibly small, so we can regard these measurements as simply $\mathrm{O}_{3}$ (see details at http://www. env.go.jp/kijun/taiki.html, in Japanese). Therefore, these data should closely reflect the ozone concentrations at the surface sites. The Hedo station data used for comparison with the Naha sondes are precisely $\mathrm{O}_{3}$.
This Japanese database contains only a subset of operational surface monitor stations in Japan. Table 6 lists information on the surface monitor data. For the Japanese ozonesondes stations, Sapporo and Tsukuba both have monitors nearby ( $<20 \mathrm{~km}$ from the launch sites) in the database, although the Tsukuba monitor record ends in 2002. The surface monitor nearest Kagoshima station is $\sim 160 \mathrm{~km}$ north, which can lead to large discrepancies between the balloon observations and the surface monitor data. The Hedo station is the nearest to Naha ( $\sim 92 \mathrm{~km}$ north-northeast), although the available record of data does not begin until 2001. It should be noted that the Naha ozonesonde station is located close to an urban area, so its ozone measurements will be affected by the urban plume, while the Hedo station is located at a remote site on the northern tip of the island. The differences in these locations are likely the primary cause of the larger offsets between the ozonesonde and surface monitor data shown in Fig. 6.

Figure 6 shows histograms of the differences between the sonde mean ozone concentrations in the lowest $100 \mathrm{~m}$ above the surface and the appropriately timed hourly surface monitor ozone concentrations near each launch site, both with and without the CFs applied to the sonde data. Table 7 provides a statistical summary of these differences. Looking at the overall data comparisons shown in Fig. 6, we see that for all four stations, the distributions of values shifts toward " 0 " with no CFs applied to the sonde data. The overall statistical comparisons in Table 7 reveal a similar result: in each case, the overall mean offset at each site is closer to " 0 " without the CF applied, improving on average from an offset of $-4.9 \pm 8.6$ with the CF to $-1.5 \pm 8.5 \mathrm{ppb}$ without (note that Naha is excluded from the "overall" average and prior to 1997 analysis since Hedo data were not available before 2001).

We examined the sensitivity of these results to three different calculations of the near surface ozonesonde readings: (1) the ozone reading at the highest ambient pressure for each ozonesonde flight; (2) the ozone reading at $10 \mathrm{~m}$ above the surface; and (3) the average ozone concentration in the first $100 \mathrm{~m}$ above the surface. The third approach resulted in the smallest mean offsets both for the data with and without the CFs applied.

Given the trends in the CFs noted in Section 2 above, we decided to further divide our analysis of the sonde-surface monitor comparisons into two periods: before and after the switch from KC-79 to KC-96 sondes, which occurred August 1997 except at Tsukuba, where it occurred in June 1997. Fig. 7 shows the histograms for the three ozonesonde stations active in 1997 divided into these two time periods and between data with and without the CFs applied. In both time periods at each station, the distributions of the differences (sonde minus surface monitor) shift toward more positive values if CFs are not applied. In general, the sonde data agree more closely with the surface monitor data when the CFs are not applied to the data. 
Sapporo $011020201993-2007$

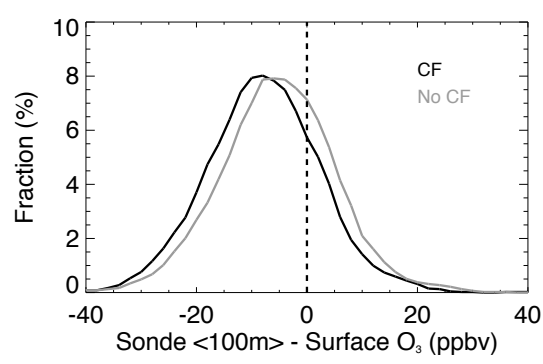

Kagoshima $402020101992-2007$

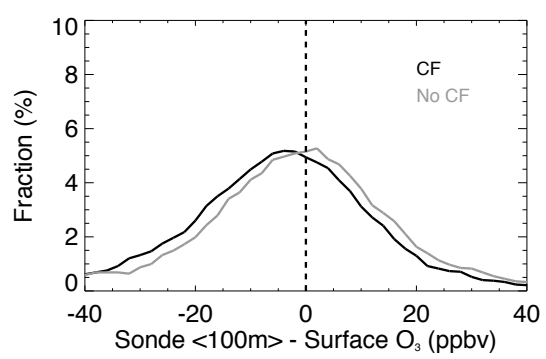

Tsukuba 084650101990 - 2002

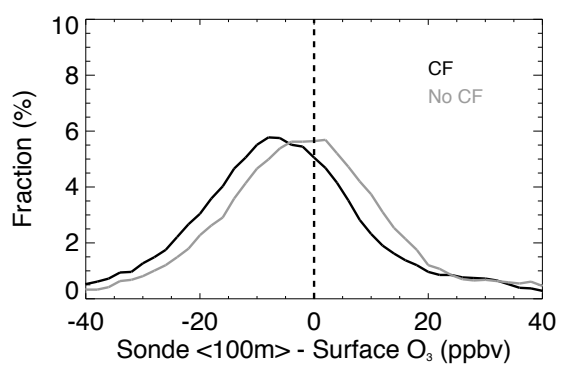

Naha Hedo 2001 - 2008

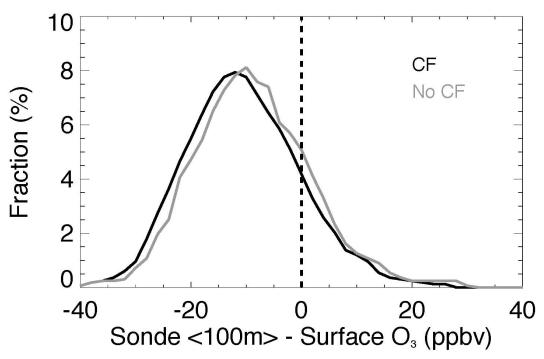

Fig. 6. Histograms of the offsets between mean ozonesonde profile data between the surface and $100 \mathrm{~m}$ above the surface with hourly-average oxidant data from the nearest surface monitor available (station number/name in plot title) in the long-term database (www.nies.go.jp/igreen/ tddisp.html), both with and without the recommended CF applied. All stations show better agreement without the CFs applied. See also Table 6 for a statistical analysis.

Table 6. Information for ground-monitors near Japanese ozonesonde stations used in this study.

\begin{tabular}{llrrrrr}
\hline & \multicolumn{5}{c}{ Surface Monitor Information } \\
\cline { 2 - 7 } $\begin{array}{l}\text { Ozonesonde } \\
\text { Station }\end{array}$ & Station & Latitude $\left({ }^{\circ} \mathrm{N}\right)$ & Longitude $\left({ }^{\circ} \mathrm{E}\right)$ & Distance $(\mathrm{km})$ & Data record & Measurement \\
\hline Sapporo & Kokusetsu & 43.082 & 141.333 & $\sim 3$ & $1993-2007$ & $\mathrm{O}_{\mathrm{x}}$ \\
Tsukuba & Kokusetsutsukuba & 36.164 & 140.183 & $\sim 12$ & $1990-2002$ & $\mathrm{O}_{\mathrm{x}}$ \\
Kagoshima & Kokusetsuoomuta & 33.030 & 130.446 & $\sim 160$ & $1992-2007$ & $\mathrm{O}_{\mathrm{x}}$ \\
Naha & Hedo & 26.856 & 128.262 & $\sim 92$ & $2001-2008$ & $\mathrm{O}_{3}$ \\
\hline
\end{tabular}

Table 7 provides the statistical analyses of trends in the data appearing in Fig. 7. At each station, the overall trend is closer to " 0 " using data without the CFs applied, with an average change from $-0.823 \pm 0.099 \mathrm{ppb} \mathrm{yr}^{-1}$ with the CFs applied to $-0.46 \pm 0.10 \mathrm{ppb} \mathrm{yr}^{-1}$ without the CFs applied. In each case, without the CF applied, we see a statistically significant change in trends from the KC-79 period to the KC-96 period. Much of the trend appears to be attributable to the change in the sonde instrument type in 1997. Overall, the trends in the sonde-surface differences are smaller without the CF applied than with it applied.

\section{Sapporo ozonesonde intercomparison}

In addition to the CI sondes, two-cell ECC ozonesondes have been launched from a second site in Sapporo, the campus of Hokkaido University $\left(41.07^{\circ} \mathrm{N}, 141.35^{\circ} \mathrm{E}\right)$, since 2003. This site is located $\sim 2 \mathrm{~km}$ from the Sapporo station launches. From 2003-2011, 58 such launches occurred, with 35 of the payloads carrying a combination of ozonesondes and frost-point hygrometers, and the remaining payloads carrying only frost-point hygrometers. Of those 35 flights with ozonesondes, 8 occurred on the same dates as the standard Sapporo station CI KC-96 ozonesonde flights, and 7 of those reached altitudes $>29 \mathrm{~km}$ before bursting, with one reaching an altitude of $32 \mathrm{~km}$. All of the Hokkaido University ozonesondes have used the NOAA configuration 
Table 7. Trends in the differences between sonde and surface measurements, and the mean offsets in those differences (Japanese ozonesonde average from the surface to $100 \mathrm{~m}$ above the surface minus surface monitor hourly ozone average) for the period 1990-2007 as computed with and without the CF applied. The average means and offsets are computed using a Monte Carlo method.

\begin{tabular}{|c|c|c|c|c|}
\hline \multirow{2}{*}{$\begin{array}{l}\text { Site } \\
\text { Overall }\end{array}$} & \multicolumn{2}{|c|}{ Sonde w/out CF } & \multicolumn{2}{|c|}{ Sonde w/CF } \\
\hline & Trend (ppbv yr $\left.{ }^{-1}\right)$ & Mean Offset (ppbv) & Trend (ppbv yr ${ }^{-1}$ ) & Mean Offset (ppbv) \\
\hline Sapporo & $-0.129(0.091)$ & $-4.3(9.0)$ & $-0.306(0.090)$ & $-6.8(9.1)$ \\
\hline 1993-1997 & $0.93(0.55)$ & $-3.2(9.5)$ & $0.33(0.59)$ & $-4.2(10.1)$ \\
\hline 1997-2007 & $-0.05(0.16)$ & $-4.8(8.8)$ & $0.07(0.15)$ & $-8.0(8.3)$ \\
\hline Tsukuba & $-0.71(0.19)$ & $0.3(16.0)$ & $-1.39(0.18)$ & $-4.2(16.1)$ \\
\hline 1990-1997 & $-2.85(0.44)$ & $1.6(16.2)$ & $-3.92(0.42)$ & $-0.8(16.4)$ \\
\hline 1997-2002 & $1.15(0.67)$ & $-1.3(15.8)$ & $1.21(0.62)$ & $-8.0(14.8)$ \\
\hline Kagoshima & $-0.54(0.22)$ & $-0.7(17.9)$ & $-0.78(0.22)$ & $-3.8(17.9)$ \\
\hline 1992-1997 & $0.80(0.91)$ & $5.4(18.3)$ & $-0.38(0.91)$ & $3.4(18.2)$ \\
\hline 1997-2005 & $2.19(0.43)$ & $-4.2(16.7)$ & $2.27(0.41)$ & $-8.0(16.3)$ \\
\hline Naha & $* *$ & $* *$ & $* *$ & $* *$ \\
\hline 1992-1997 & $* *$ & $* *$ & $* *$ & $* *$ \\
\hline 2001-2008 & $0.36(0.32)$ & $-7.7(9.4)$ & $0.61(0.30)$ & $-9.5(9.1)$ \\
\hline Average* & $-0.46(0.10)$ & $-1.5(8.5)$ & $-0.823(0.099)$ & $-4.9(8.6)$ \\
\hline 1990-1997* & $-0.36(0.38)$ & $1.3(8.7)$ & $-1.32(0.39)$ & $-0.5(8.8)$ \\
\hline 1997-2007* & $0.92(0.22)$ & $-3.4(8.2)$ & $1.04(0.20)$ & $-8.0(7.8)$ \\
\hline
\end{tabular}

*Naha data are not included in averages. ** No data for Hedo station is available to compare with Naha sonde until 2001, so overall average trend form early 1990's to 2007 is also not presented.

with an En-Sci ECC, TMAX-C interface board, and Vaisala RS80 radiosonde. Hokkaido University sondes are processed with the NOAA STRATO software (http://cires.colorado. edu/ voemel/strato/strato.html). The 10 flights in August 2008 and 12 flights in August/September of 2009 used $0.5 \%$ buffered potassium iodide cathode solutions while the remaining flights used $2 \%$ unbuffered potassium iodide cathode solutions. No CFs are applied to the Hokkaido University data. The BBC is used to compute the above-burst column ozone.

Table 8 summarizes the column ozone observations for each of the 7 coincident flights, including the ECC Hokkaido University sonde columns, the Earth Probe Total Ozone Mapping Spectrometer (EPTOMS) (2004 flights) or OMI (2005-2009 flights) columns over the Sapporo station $\left(43.06^{\circ} \mathrm{N}, 141.33^{\circ} \mathrm{E}\right)$, and the Sapporo CI KC-96 ozonesonde columns, calculated both with and without the CFs. The mean differences in the agreements between the sondes and satellite columns are not statistically significantly different (see the second to last row of Table 8), due both to the scatter and the small number of coincident sondes, although the mean difference between TOMS/OMI columns and the columns from the Sapporo CI KC-96 sondes with the CFs applied shows the smallest standard deviation. This result is not surprising since the application of the CFs result in perfect agreement between the sonde columns and the collo- cated Dobson instrument at the Sapporo station launch site. Nevertheless, for two of the flights (2004-05-26 adn 200807-29), the ECC and CI KC-96 without the CF ozonesonde columns agree with one another better than either agrees with OMI/EPTOMS or the Dobson instrument. In fact, the overall agreement between the ECC sonde columns and the Sapporo CI KC-96 sonde columns is slightly better for the uncorrected data, though not statistically significantly so (see the last row of Table 8). The explanations for these observations are unclear, but they enhance the case that caution must be used when applying the correction factors based on either satellite or ground-based column measurements.

Table 9 presents an overall comparison of the columns from the ECC and CI sondes (both with and without the CFs) to the satellite columns from EPTOMS (1996-2005) and OMI (2004-2009). The best agreement is found for the corrected CI sonde data, but that agreement is not statistically significantly different from the agreement seen between the ECC Hokkaido University sondes and satellite observations. The worst agreement and largest scatter is seen with comparisons of the CI sonde columns without the CFs applied and the satellite columns, indicating that some correction to the profiles is necessary.

To gain insight as to how best to correct the CI sonde profiles, we examine the mean percent differences between the ECC Hokkaido University ozonesonde profiles and those 


\section{Sapporo Ozonesonde Profile Differences}

Sapporo $011020201993-2007$

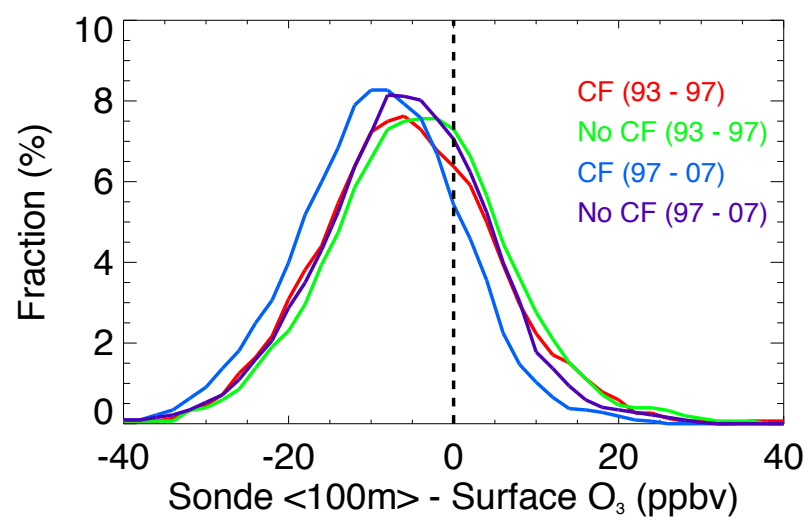

Tsukuba $084650101990-2002$

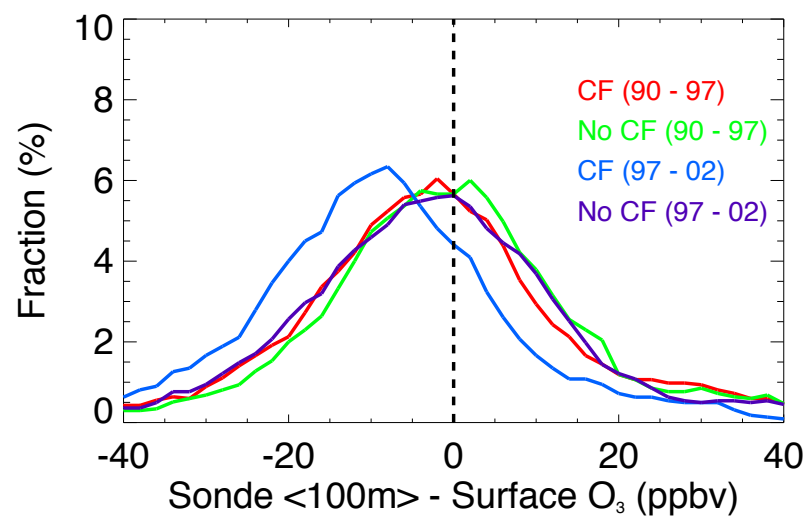

Kagoshima $402020101992-2007$

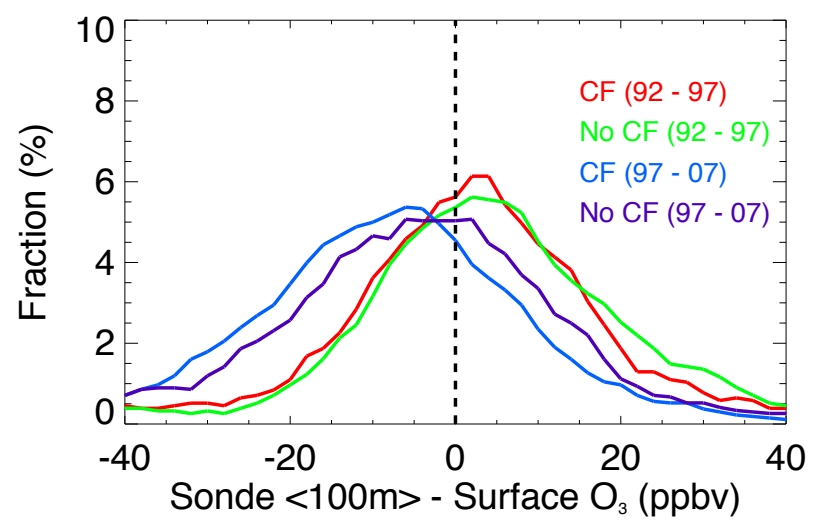

Fig. 7. As in Fig. 6, but with data separated into periods before and after 1997. See also Table 6 for a statistical analysis.

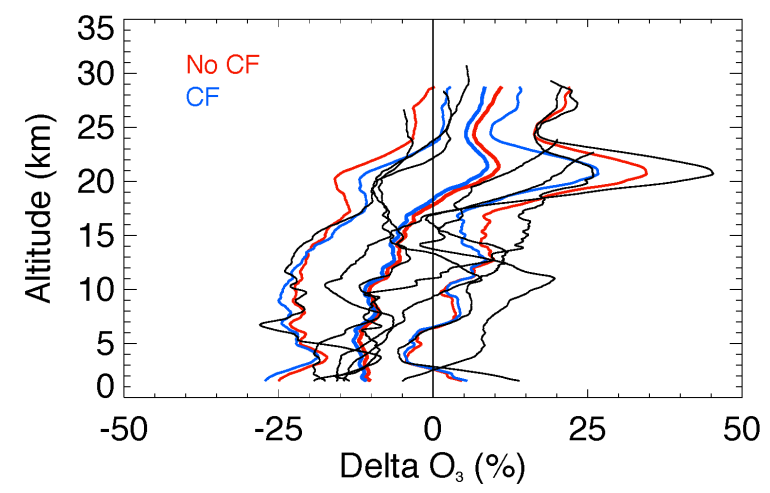

Fig. 8. A comparison of the mean (thick) and mean $\pm 1 \sigma$ percent differences between the En-Sci ECC sondes launched from Hokkaido University and the CI sondes from the Sapporo station ((CI-ECC)/ECC), both with (blue) and without (red) the CFs applied for the 7 launches that occurred on the same days. Only the ECC sondes reaching least $29 \mathrm{~km}$ altitude before bursting (2004-0210, 2004-05-26, 2005-01-25, 2006-09-06, 2008-07-29, 2009-08-12, and 2009-08-18) are shown. The percent differences for the individual flights appear as the black lines. A 3-km boxcar smoothing function is applied to the percent difference data due to the limited number of coincidences.

from the CI ozonesondes for the 7 coincident flights listed in Table 8. The overall comparison is shown in Fig. 8, with comparisons between the ECC sonde profiles and both the corrected (blue) and uncorrected (red) CI KC-96 sonde profiles. Data from each of the 7 comparisons appear as the black curves in Fig. 8. Here, the percent difference is calculated as the $100 \times(\mathrm{CI}-\mathrm{ECC}) / \mathrm{ECC}$. Again, we are limited by the small number of coincidences, which results in statistically insignificant differences. Nevertheless, we note that throughout the troposphere, the mean differences between the Sapporo CI KC-96 profiles and the Hokkaido University ECC sonde profile differences are closer to 0 without the CFs applied, while in the stratosphere (above $18 \mathrm{~km}$ ), the reverse is true. With the majority of the ozone present in the ozone layer between 20 and $30 \mathrm{~km}$, the CFs are heavily influenced by the stratospheric concentrations. In looking at the mean profiles, however, we see in Fig. 8 that the tropospheric differences are negative while the stratospheric differences are positive, meaning that applying the CFs to the entire profile exacerbates the differences in the troposphere, though in the limited 7 cases that make up the data in Fig. 8, the differences between the mean profiles with and without the CFs applied are not statistically significant. These results are consistent with the findings in JOSIE 2000 (Smit and Sträter, 2004) and JOSIE 1996 (Smit and Kley, 1998).

We also note that the mean CF applied in the 7 matching cases is $1.028 \pm 0.082$, which is higher than the historical record, which has a mean of $0.927 \pm 0.093$, indicating 
Table 8. Column ozone amounts for Earth Probe TOMS (EPTOMS) or Ozone Mapping Instrument (OMI), electrochemical concentration cell (ECC) ozonesondes launched at Hokkaido University, and the Carbon Iodine ozonesondes launched at Sapporo both without and with correction factors applied. Mean differences between the sonde columns and TOMS/OMI columns are shown, with $1 \sigma$ in parenthesis. Mean differences of the CI columns with and without the correction factors (CF) applied are shown relative to the ECC columns, with $1 \sigma$ in parenthesis. For the flight of 2009-08-12 (marked*), no OMI overpass is available, so the overpasses from the prior and next day are averaged.

\begin{tabular}{lrrrr}
\hline & $\begin{array}{r}\text { TOMS/ } \\
\text { OMI } \\
\text { (DU) }\end{array}$ & $\begin{array}{r}\text { ECC } \\
\text { (DU) }\end{array}$ & $\begin{array}{r}\text { CI, KC-96 } \\
\text { w/out CF } \\
\text { (DU) }\end{array}$ & $\begin{array}{r}\text { CI, KC-96 } \\
\text { w/CF } \\
\text { (DU) }\end{array}$ \\
\hline $2004-02-10$ & 403.4 & 412.2 & 444.6 & 417 \\
$2004-05-26$ & 346.4 & 318.6 & 328.3 & 353 \\
$2005-01-25$ & 401.2 & 379.0 & 426.7 & 397 \\
$2006-09-06$ & 268.8 & 281.7 & 275.5 & 280 \\
$2008-07-29$ & 306.8 & 261.9 & 260.2 & 303 \\
$2009-08-12$ & $276.4^{*}$ & 275.4 & 269.2 & 273 \\
$2009-08-18$ & 291.8 & 307.7 & 283.1 & 300 \\
\hline Mean difference w/TOMS/OMI & N/A & $-8(23)$ & $-1(29)$ & $4.0(7.7)$ \\
\hline Mean difference w/ECC & N/A & N/A & $-7(25)$ & $-12(19)$ \\
\hline
\end{tabular}

Table 9. Differences in column ozone amounts between ozonesondes and Earth Probe TOMS (EPTOMS) and Ozone Mapping Instrument (OMI). Data from electrochemical concentration cell (ECC) ozonesondes launched at Hokkaido University (which use the En-Sci two cell KI technology) and the Carbon Iodine (CI) ozonesondes launched at Sapporo both without and with correction factors (CF) applied. The data include the mean differences, $1 \sigma$ in parenthesis, and the number of flights compared after the comma.

\begin{tabular}{llll}
\hline \multirow{3}{*}{ Satellite } & $\begin{array}{l}\text { ECC Hokkaido } \\
\text { Univ. Sondes } \\
(2003-2009)\end{array}$ & $\begin{array}{l}\text { CI Sapporo } \\
\text { Sondes w/out CF } \\
(1996-2009)\end{array}$ & $\begin{array}{l}\text { CI Sapporo } \\
\text { Sondes w/CF } \\
(1996-2009)\end{array}$ \\
& DU (DU), \# & DU (DU), \# \\
\hline $\begin{array}{l}\text { EPTOMS } \\
\text { thru 2005) }\end{array}$ & $-12(15), 11$ & $34(29), 342$ & $-5(13), 342$ \\
\hline $\begin{array}{l}\text { OMI } \\
\text { since 2004) }\end{array}$ & $6(16), 25$ & $26(24), 157$ & $1.4(8.7), 157$ \\
\hline
\end{tabular}

that our sample may not be representative: the profiles in our sample have smaller ozone concentrations than typical in the larger data set. This bias is apparent in the fact that three of the black curves from individual flights appearing in Fig. 8 remain negative (or nearly so) from the surface through the ozone layer.

In summary, the profile data comparison, though not statistically significant, suggests that while applying CFs in the stratosphere is helpful for improving agreement with satellite and Dobson instrument columns as well as with the stratospheric portion of the ozone profiles observed in the correlated ECC sondes from Hokkaido University, the tropospheric comparisons may be improved without the application of the $\mathrm{CFs}$, a result consistent with the findings of the SPARC-IOC-GAW Report (1998). Furthermore, the ECC sonde agreement with the satellite observations is statistically similar to that found with the corrected CI sonde data, suggesting the ECC technology may well be the better ap- proach. Since late 2009, all Japanese stations have switched from the CI KC-96 sondes to the ECC sondes, so the problems explored in this paper may well be moot now.

\section{Conclusions and recommendations}

This paper has provided an analysis of the application of the correction factor (CF) for ozonesonde profile data based on observations from the four Japanese ozonesonde stations, TOMS and OMI overpass column data, ground-based Dobson instrument column data (used to determine the CFs for the Japanese sounding in the WOUDC database), and surface monitor data from sites nearby to the ozonesonde stations. We find that while CFs based on sonde column to Dobson instrument column ratios result in better agreement with the satellite observations, the agreement between the sonde reported ozone concentration measurements and those of the nearby surface monitors deteriorates. 
Comparisons of ozonesonde profiles from Hokkaido University (which employed the standard ECC technology) with those of the Sapporo station (which employed the CI KC-96 technology) indicate that while the application of CFs improves agreement with the ozone concentrations in the stratosphere (and with the total columns measured by other instruments), it may make agreement in the troposphere worse. Comparisons of mean ozone in the first $100 \mathrm{~m}$ above the ground from the ozonesonde profiles and nearby surface ozone observations at the time of launch confirm that agreement is better without applying the CFs.

We found that the CFs of KC-79 sondes flown from 19791997 had a mean of $0.962 \pm 0.055$, while the CFs of KC-96 sondes flown from 1997-2009 had a mean of $0.901 \pm 0.038$. This result contradicts the apparent improvement in CFs for the KC-96 sondes over the KC-79 sondes found in the JOSIE studies. If we limit our analysis to just the instruments flown during the years of the JOSIE studies (1996 and 2000), we find the KC-79 sondes in 1996 had a mean CF of $0.890 \pm 0.040$ and the KC-96 sondes in 2000 had a mean CF of $0.884 \pm 0.039-$ the two technologies show similar performance. JOSIE 1996 found a mean CF of $0.91 \pm 0.10$ for the KC-79 sondes and JOSIE 2000 found a mean CF of $0.96 \pm 0.02$ for the KC-96 sondes. While the differences are not statistically significant, they did suggest some improvement from KC-79 to KC-96 sonde technology that does not seem to be reproduced by the flight data we analyzed. Further investigation of this issue may well be warranted.

Disturbingly, we found the CFs at the Japanese ozonesonde stations exhibit trends over the period 19902009, with differing trends during the period 1990-1997 (when KC-79 sondes were flown) and the period 1997-2009 (when KC-96 sondes were flown). The trends remain even when analyzing the $\mathrm{CF}_{\mathrm{BB}}$ data that used the $\mathrm{BBC}$ rather than the CMR assumption to compute the above-burst column ozone. These trends are as yet unexplained, although given the consistency of the downward trend from 1993-1999 at all four Japanese stations and of the upward trend from 19992009 , we wonder about the possibility of a chemical interference mechanism, perhaps resulting from the altered chemical composition of the stratosphere due to the eruption of Mt. Pinatubo. Our preliminary investigation of the CFs at 9 other ozonesonde stations with data in the WOUDC database suggests that similar trends in CFs are not present over the same periods. We intend to expand this investigation and analysis in future work.

Regardless of its cause, the presence of the CF trends at the Japanese stations warrants caution when employing ozonesonde data with CFs applied to the entire profile in trend calculations. Our findings may require the community to revisit previously published tropospheric ozone trend results that have included the Japanese sonde data. Since the CFs do result in better agreement of the sonde columns with correlative measurements, and since most of the ozone is in the stratosphere, one possible approach to consider, which we recommend based on this study, which was suggested in the SPARC-IOC-GAW Report (1998), and which Logan et al. (1999) noted was suggested around the time of their paper (uncited reference) is only to apply CFs to the stratospheric portion of the profiles. Such an approach would require a new method for calculating the CFs. Here would be our recommendation: (1) integrate the sondes to the tropopause; (2) add the balloon-burst climatological column (using the actual balloon burst altitude) to the tropospheric column; (3) subtract the sum of partial columns computed in \#1 and \#2 from the correlative column measurement (Dobson, Brewer, TOMS/OMI); (4) compute the sonde column above the tropopause; and (5) take the ratio of the correlative stratospheric column in \#3 to the sonde stratospheric column in \#4 - that is the new CF. Some iteration may be required so that a discontinuity between the tropospheric and stratospheric portions of the ozonesonde profile would not appear.

We also note that the CFs (computed with columns that used the CMR above-burst assumption) show a dependence on burst altitude below $32 \mathrm{~km}(10.5 \mathrm{hPa})$. We therefore recommend only using ozonesonde data from those profiles that extend to at least $32 \mathrm{~km}$ altitude. Finally, we found that using the McPeters et al. (1997) BBC rather than a CMR assumption for calculating the above-burst height columns resulted in better agreement between the sonde columns and the ground-based Dobson instrument columns and allowed for analysis of sonde data with lower burst altitudes. In particular, it appears that the utility of the column data from sondes using the BBC can be extended down to $\sim 26 \mathrm{hPa}$ burst altitude. We therefore recommend using the balloon-burst climatology for computing total columns with ozonesonde data. Again, all of our analyses should be expanded to other ozonesonde stations in the WOUDC database, since most stations in that database apply the CF to the entire profile, as has been done at the Japanese sounding stations.

Acknowledgements. Funding for this work was provided by a Fulbright Scholar Grant from the Japan-U.S. Educational Commission and NASA's Aura Data Validation Program (D. Considine and E. Hilsenrath, program managers). Special thanks to my hosts in Japan during my Fulbright. We thank reviewer Neil Harris and the other anonymous reviewer for very helpful comments that have led to significant improvements in the final version of this manuscript.

Edited by: A. Pszenny

\section{References}

Balis, D., Kroon, M., Koukouli, M. E., Brinksma, E. J., Labow, G., Veefkind, J. P., and McPeters, R. D.: Validation of Ozone Monitoring Instrument total ozone column measurements using Brewer and Dobson spectrophotometer ground-based observations, J. Geophys. Res., 112, D24S46, doi:10.1029/2007jd008796, 2007. 
Bian, J., Gettelman, A., Chen, H., and Pan, L. L.: Validation of satellite ozone profile retrievals using Beijing ozonesonde data, J. Geophys. Res., 112, D06305, doi:10.1029/2006jd007502, 2007.

Brinksma, E. J., Bracher, A., Lolkema, D. E., Segers, A. J., Boyd, I. S., Bramstedt, K., Claude, H., Godin-Beekmann, S., Hansen, G., Kopp, G., Leblanc, T., McDermid, I. S., Meijer, Y. J., Nakane, H., Parrish, A., von Savigny, C., Stebel, K., Swart, D. P. J., Taha, G., and Piters, A. J. M.: Geophysical validation of SCIAMACHY Limb Ozone Profiles, Atmos. Chem. Phys., 6, 197-209, doi:10.5194/acp-6-197-2006, 2006.

Bruehl, C., Drayson, S. R., Russell, J. M., III, Crutzen, P. J., McInerney, J. M., Purcell, P. N., Claude, H., Gernandt, H., McGee, T. J., McDermid, I. S., and Gunson, M. R.: Halogen Occultation Experiment ozone channel validation, J. Geophys. Res., 101, 10217-10240, doi:10.1029/95jd02031, 1996.

Cunnold, D. M., Chu, W. P., Barnes, R. A., McCormick, M. P., and Veiga, R. E.: Validation of SAGE II Ozone Measurements, J. Geophys. Res., 94, 8447-8460, doi:10.1029/JD094iD06p08447, 1989.

Dobson, G. M. B.: Atmospheric ozone and the movement of air in the stratosphere, Pure Appl. Geophys., 106-108, 1520-1530, 1973.

Fioletov, V. E., Labow, G., Evans, R., Hare, E. W., K^hler, U., McElroy, C. T., Miyagawa, K., Redondas, A., Savastiouk, V., Shalamyansky, A. M., Staehelin, J., Vanicek, K., and Weber, M.: Performance of the ground-based total ozone network assessed using satellite data, J. Geophys. Res., 113, D14313, doi:10.1029/2008jd009809, 2008.

Fishman, J., Watson, C. E., Larsen, J. C., and Logan, J. A.: Distribution of Tropospheric Ozone Determined From Satellite Data, J. Geophys. Res., 95, 3599-3617, doi:10.1029/JD095iD04p03599, 1990.

Froidevaux, L., Read, W. G., Lungu, T. A., Cofield, R. E., Fishbein, E. F., Flower, D. A., Jarnot, R. F., Ridenoure, B. P., Shippony, Z., Waters, J. W., Margitan, J. J., McDermid, I. S., Stachnik, R. A., Peckham, G. E., Braathen, G., Deshler, T., Fishman, J., Hofmann, D. J., and Oltmans, S. J.: Validation of UARS Microwave Limb Sounder ozone measurements, J. Geophys. Res., 101, 10017-10060, doi:10.1029/95jd02325, 1996.

Hare, E. W., Carty, E. J., Fioletov, V., and Wardle, D. I.: User Guide to the WMO/GAW World Ozone Data Centre, Version 3.0, Environment Canada, 2007.

Hasebe, F. and Yoshikura, Y.: Long-term Ozone Trend Depicted by Ozonesonde Observations over Japan, SOLA, 2, 84-87, 2006.

Hayashida, S., Urita, N., Noguchi, K., Liu, X., and Chance, K.: Spatiotemporal variation in tropospheric column ozone over East Asia observed by GOME and ozonesondes, SOLA, 4, 117-120, doi:10.2151/sola2008-030, 2008.

Jiang, Y. B., Froidevaux, L., Lambert, A., Livesey, N. J., Read, W. G., Waters, J. W., Bojkov, B., Leblanc, T., McDermid, I. S., Godin-Beekmann, S., Filipiak, M. J., Harwood, R. S., Fuller, R. A., Daffer, W. H., Drouin, B. J., Cofield, R. E., Cuddy, D. T., Jarnot, R. F., Knosp, B. W., Perun, V. S., Schwartz, M. J., Snyder, W. V., Stek, P. C., Thurstans, R. P., Wagner, P. A., Allaart, M., Andersen, S. B., Bodeker, G., Calpini, B., Claude, H., Coetzee, G., Davies, J., De Backer, H., Dier, H., Fujiwara, M., Johnson, B., Kelder, H., Leme, N. P., Konig-Langlo, G., Kyro, E., Laneve, G., Fook, L. S., Merrill, J., Morris, G., Newchurch, M., Oltmans, S., Parrondos, M. C., Posny, F., Schmidlin, F., Skrivankova, P.,
Stubi, R., Tarasick, D., Thompson, A., Thouret, V., Viatte, P., Vomel, H., von Der Gathen, P., Yela, M., and Zablocki, G.: Validation of Aura Microwave Limb Sounder Ozone by ozonesonde and lidar measurements, J. Geophys. Res.-Atmos., 112, D24s34, doi:10.1029/2007jd008776, 2007.

Keim, E. R., Fahey, D. W., Del Negro, L. A., Woodbridge, E. L., Gao, R. S., Wennberg, P. O., Cohen, R. C., Stimpfle, R. M., Kelly, K. K., Hintsa, E. J., Wilson, J. C., Jonsson, H. H., Dye, J. E., Baumgardner, D., Kawa, S. R., Salawitch, R. J., Proffitt, M. H., Loewenstein, M., Podolske, J. R., and Chan, K. R.: Observations of large reductions in the NO/NOy ratio near the mid-latitude tropopause and the role of heterogeneous chemistry, Geophys. Res. Lett., 23, 3223-3226, doi:10.1029/96gl02593, 1996.

Kivi, R., Kyrö, E., Turunen, T., Harris, N. R. P., von der Gathen, P., Rex, M., Andersen, S. B., and Wohltmann, I.: Ozonesonde observations in the Arctic during 1989-2003: Ozone variability and trends in the lower stratosphere and free troposphere, J. Geophys. Res., 112, D08306, doi:10.1029/2006jd007271, 2007.

Kobayashi, J. and Toyama, Y.: On various methods of measuring the vertical distribution of atmospheric ozone (III) - Carbon iodine type chemical ozonesonde, Pap. Met. Geophys., 17, 113126, 1966.

Komhyr, W. D.: Electrochemical concentration cells for gas analysis, Ann. Geophys., 25, 203-210, 1969,

http://www.ann-geophys.net/25/203/1969/.

Komhyr, W. D.: Operations handbook - Ozone measurements to $40 \mathrm{~km}$ altitude with model 4A-ECC-ozone sondes, NOAA Techn. Memorandum, ERL-ARL-149, 1986.

Komhyr, W. D., Barnes, R. A., Brothers, G. B., Lathrop, J. A., and Opperman, D. P.: Electrochemical concentration cell ozonesonde performance evaluation during STOIC 1989, J. Geophys. Res., 100, 9231-9244, 1995a.

Komhyr, W. D., Connor, B. J., McDermid, I. S., McGee, T. J., Parrish, A. D., and Margitan, J. J.: Comparison of STOIC 1989 ground-based lidar, microwave spectrometer, and dobson spectrophotometer Umkehr ozone profiles with ozone profiles from balloon-borne electrochemical concentration cell ozonesondes, J. Geophys. Res., 100, 9273-9282, 1995b.

Kroon, M., de Haan, J. F., Veefkind, J. P., Froidevaux, L., Wang, R., Kivi, R., and Hakkarainen, J. J.: Validation of operational ozone profiles from the Ozone Monitoring Instrument, J. Geophys. Res., 116, D18305, doi:10.1029/2010jd015100, 2011.

Krzyscin, J., Krizan, P., and JarosÇawski, J.: Long-term changes in the tropospheric column ozone from the ozone soundings over Europe, Atmos. Environ., 41, 606-616, doi:10.1016/j.atmosenv.2006.08.026, 2007.

Liu, X., Chance, K., Sioris, C. E., Kurosu, T. P., and Newchurch, M. J.: Intercomparison of GOME, ozonesonde, and SAGE II measurements of ozone: Demonstration of the need to homogenize available ozonesonde data sets, J. Geophys. Res., 111, D14305, doi:10.1029/2005jd006718, 2006.

Logan, J. A.: Tropospheric Ozone: Seasonal Behavior, Trends, and Anthropogenic Influence, J. Geophys. Res., 90, 10463-10482, doi:10.1029/JD090iD06p10463, 1985.

Logan, J. A.: Trends in the vertical distribution of ozone - an analysis of ozonesonde data, J. Geophys. Res., 99, 25553-25585, 1994.

Logan, J. A., Megretskaia, I. A., Miller, A. J., Tiao, G. C., Choi, D., Zhang, L., Stolarski, R. S., Labow, G. J., Hollandsworth, S. M., 
Bodeker, G. E., Claude, H., De Muer, D., Kerr, J. B., Tarasick, D. W., Oltmans, S. J., Johnson, B., Schmidlin, F., Staehelin, J., Viatte, P., and Uchino, O.: Trends in the vertical distribution of ozone: A comparison of two analyses of ozonesonde data, J. Geophys. Res., 104, 26373-26399, 1999.

McPeters, R. D. and Labow, G. J.: An assessment of the accuracy of 14.5 years of Nimbus 7 TOMS version 7 ozone data by comparison with the Dobson network, Geophys. Res. Lett., 23, 36953698, doi:10.1029/96g103539, 1996.

McPeters, R. D. and Labow, G. J.: Climatology: An MLS and sonde derived ozone climatology for satellite retrieval algorithms, J. Geophys. Res., 117, D10303, doi:10.1029/2011JD017006, 2012.

McPeters, R. D., Labow, G. J., and Johnson, B. J.: A satellitederived ozone climatology for balloonsonde estimation of total column ozone, J. Geophys. Res., 102, 8875-8885, doi:10.1029/96jd02977, 1997.

Miller, A. J., Tiao, G. C., Reinsel, G. C., Wuebbles, D., Bishop, L., Kerr, J., Nagatani, R. M., DeLuisi, J. J., and Mateer, C. L.: Comparisons of observed ozone trends in the stratosphere through examination of Umkehr and balloon ozonesonde data, J. Geophys. Res., 100, 11209-11217, doi:10.1029/95jd00632, 1995.

Miller, A. J., Cai, A., Tiao, G., Wuebbles, D. J., Flynn, L. E., Yang, S.-K., Weatherhead, E. C., Fioletov, V., Petropavlovskikh, I., Meng, X.-L., Guillas, S., Nagatani, R. M., and Reinsel, G. C.: Examination of ozonesonde data for trends and trend changes incorporating solar and Arctic oscillation signals, J. Geophys. Res., 111, D13305, doi:10.1029/2005jd006684, 2006.

Naja, M. and Akimoto, H.: Contribution of regional pollution and long-range transport to the Asia-Pacific region: Analysis of long-term ozonesonde data over Japan, J. Geophys. Res., 109, D21306, doi:10.1029/2004jd004687, 2004.

Nassar, R., Logan, J. A., Worden, H. M., Megretskaia, I. A., Bowman, K. W., Osterman, G. B., Thompson, A. M., Tarasick, D. W., Austin, S., Claude, H., Dubey, M. K., Hocking, W. K., Johnson, B. J., Joseph, E., Merrill, J., Morris, G. A., Newchurch, M., Oltmans, S. J., Posny, F., Schmidlin, F. J., Vomel, H., Whiteman, D. N., and Witte, J. C.: Validation of Tropospheric Emission Spectrometer (TES) nadir ozone profiles using ozonesonde measurements, J. Geophys. Res., 113, D15s17, doi:10.1029/2007jd008819, 2008.

Oltmans, S. J., Lefohn, A. S., Harris, J. M., Galbally, I., Scheel, H. E., Bodeker, G., Brunke, E., Claude, H., Tarasick, D., Johnson, B. J., Simmonds, P., Shadwick, D., Anlauf, K., Hayden, K., Schmidlin, F., Fujimoto, T., Akagi, K., Meyer, C., Nichol, S., Davies, J., Redondas, A., and Cuevas, E.: Long-term changes in tropospheric ozone, Atmos. Environ., 40, 3156-3173, doi:10.1016/j.atmosenv.2006.01.029, 2006.

Osterman, G. B., Kulawik, S. S., Worden, H. M., Richards, N. A. D., Fisher, B. M., Eldering, A., Shephard, M. W., Froidevaux, L., Labow, G., Luo, M., Herman, R. L., Bowman, K. W., and Thompson, A. M.: Validation of Tropospheric Emission Spectrometer (TES) measurements of the total, stratospheric, and tropospheric column abundance of ozone, J. Geophys. Res., 113, D15S16, doi:10.1029/2007jd008801, 2008.
Rault, D. F. and Taha, G.: Validation of ozone profiles retrieved from Stratospheric Aerosol and Gas Experiment III limb scatter measurements, J. Geophys. Res., 112, D13309, doi:10.1029/2006jd007679, 2007.

Smit, H. G. and Kley, H.: Julich Ozone Sonde Intercomparison Experiment, WMO Global Atmosphere Watch report series No. 130, (Technical Document No. 926), World Meteorological Organization, Geneva, 108 pp., 1998.

Smit, H. G. and Sträter, W. (eds.): Julich Ozone Sonde Intercomparison Experiment 2000, WMO Global Atmosphere Watch report series No. 158 (Technical Document No. 1225), World Meteorological Organization, Geneva, 147 pp., 2004.

Smit, H. G. J., Sträter, W., Johnson, B. J., Oltmans, S. J., Davies, J., Tarasick, D. W., Hoegger, B., Stubi, R., Schmidlin, F. J., Northam, T., Thompson, A. M., Witte, J. C., Boyd, I., and Posny, F.: Assessment of the performance of ECC-ozonesondes under quasi-flight conditions in the environmental simulation chamber: Insights from the Juelich Ozone Sonde Intercomparison Experiment (JOSIE), J. Geophys. Res., 112, D19306, doi:10.1029/2006jd007308, 2007.

Solomon, S., Portmann, R. W., Garcia, R. R., Randel, W., Wu, F., Nagatani, R., Gleason, J., Thomason, L., Poole, L. R., and McCormick, M. P.: Ozone depletion at mid-latitudes: Coupling of volcanic aerosols and temperature variability to anthropogenic chlorine, Geophys. Res. Lett., 25, 1871-1874, doi:10.1029/98gl01293, 1998.

SPARC-IOC-GAW: Assessment of Trends in the Vertical Distribution of Ozone, SPARC report No.1, WMO Global Ozone Research and Monitoring Project Report No. 43 Geneva, 1998.

Thompson, A. M. and Hudson, R. D.: Tropical tropospheric ozone (TTO) maps from Nimbus 7 and Earth Probe TOMS by the modified-residual method: Evaluation with sondes, ENSO signals, and trends from Atlantic regional time series, J. Geophys. Res., 104, 26961-26975, doi:10.1029/1999jd900470, 1999.

WMO: Quality Assurance and Quality Control for Ozonesonde Measurements in GAW, Geneva, Switzerland, WMO Rep. 201, 2011

Worden, H. M., Logan, J. A., Worden, J. R., Beer, R., Bowman, K., Clough, S. A., Eldering, A., Fisher, B. M., Gunson, M. R., Herman, R. L., Kulawik, S. S., Lampel, M. C., Luo, M., Megretskaia, I. A., Osterman, G. B., and Shephard, M. W.: Comparisons of Tropospheric Emission Spectrometer (TES) ozone profiles to ozonesondes: Methods and initial results, J. Geophys. Res., 112, D03309, doi:10.1029/2006jd007258, 2007.

Ziemke, J. R., Chandra, S., and Bhartia, P. K.: A 25-year data record of atmospheric ozone in the Pacific from Total Ozone Mapping Spectrometer (TOMS) cloud slicing: Implications for ozone trends in the stratosphere and troposphere, J. Geophys. Res., 110, D15105, doi:10.1029/2004jd005687, 2005. 